\title{
New Permian ostracods from Greece (Hydra Island)
}

\author{
SYLVIE CRASQUIN-SOLEAU ${ }^{1} \&$ AYMON BAUD ${ }^{2}$ \\ ${ }^{1}$ CNRS Université Pierre et Marie Curie, Departement Géologie Sédimentaire, T.15-25, E.4, case 104, 75252 Paris cedex 05, France. \\ ${ }^{2}$ Musée de Géologie, UNIL, BFSH2, CH-1012 Lausanne, Switzerland.
}

\begin{abstract}
A new Permian (Late Asselian-Dorashamian) ostracod fauna (66 species belonging to 35 genera) from Hydra Island (Greece) is described. Twelve new species are described: Hollinella ( $P$.) hydraensis Crasquin-Soleau n.sp, Bairdia episkopiensis Crasquin-Soleau n.sp., Bairdia rigasensis CrasquinSoleau n.sp., Bairdia thikiaensis Crasquin-Soleau n.sp., Chamishaella marmariensis Crasquin-Soleau n.sp., Cypridina gussevaae Crasquin-Soleau n.sp., Cyathus barmariensis Crasquin-Soleau n.sp., Cyathus klimakiensis Crasquin-Soleau n.sp., Bairdiacypris bistiensis Crasquin-Soleau n.sp., Shishaella hellenensis Crasquin-Soleau n.sp., Bairdia ishizakii Crasquin-Soleau n.sp., Petasobairdia kozuri Crasquin-Soleau n.sp. Forty-four other species are figured. This assemblage is characteristic of a shallow water platform. The palaeobiogeographic relationships are presented and represent significant additions to the Permian PalaeoTethyan ostracod faunas. J. Micropalaeontol. 17(2): 131-152, December 1998.
\end{abstract}

\section{GEOLOGICAL SETTING}

Hydra Island is located off the southeast coast of the Greek Argolis Penninsula (Fig.1). This island is about $21 \mathrm{~km}$ long and $5 \mathrm{~km}$ wide. Due to the excellent exposures of Palaeozoic and Mesozoic rocks, this island has received much attention from micropalaeontologists, stratigraphers and sedimentologists. Permian strata contain abundant algae, fusulinaceans and other foraminifera, conodonts (Renz \& Reichel, 1946; Stow, 1975; Nestell \& Wardlaw, 1987; Jenny-Deshusses \& Baud, 1989; Baud et al., 1991; Grant et al., 1991; Vachard et al., 1995) and brachiopods (Nestell \& Grant, 1987; Grant, 1995). Four species of ostracods were described from the Upper Permian of Hydra Island (USNM localities 9260 and $9262^{*}$ ) in two papers (Kornicker \& Sohn, 1976; Sohn, 1978). An account of the geology of Hydra is given by Römermann $(1968,1969)$ who also published a detailed geological map (Römermann et al., 1981). More recent maps have been published which focus on Permian (Grant et al., 1991) and Triassic units (Angiolini et al., 1992).

The Permian rocks of Hydra are part of the giant Permian carbonate platform (Baud et al., 1993) and contain one of the most fossiliferous sequences of Western Tethys. This sequence occurs within two groups of tectonic slices (Grant et al., 1991). The Permian units are at least $500 \mathrm{~m}$ thick and range from Asselian to Dorashamian in age. According to the lithology and age, this sequence has been subdivided by Baud et al. (1991) into three groups and 10 formations. In stratigraphic order (Fig. 2), there are the Thikia Group (five formations), the Klimaki Group (three formations) and the Barmari Group (two formations) (Grant et al., 1991).

The Thikia Group consists of five formations: in stratigraphic order, Nisitsa, Ormos, Lehusis, Mamantos and Cape Rigas, from Late Asselian to Early Artinskian. In this group, only two levels are studied here. They are at the top of the Lehusis Formation and at the base of the Cape Rigas Formation. The Lehusis formation (50-100 m thick) consists mainly of Tubiphytes-algal-sponge carbonate buildups. The Cape Rigas Formation ( $28 \mathrm{~m}$ thick) is subdivided into a lower calcareous unit (Early Artinskian), a middle calcareous and shaly unit (Late Early Artinskian), and an upper shaly unit (no typical fauna) (Grant et al., 1991).

The Klimaki Group is subdivided into three formations: Riga, Cape Bisti and Marmari. Only the last one contains ostracods and is of Late Murgabian age. It consists of two calcarodolomitic cycles, 50 and $100 \mathrm{~m}$ thick, respectively (Grant $e t$ al., 1991).

The Barmari Group is subdivided into two formations, the Episkopi Formation which fits below the Miras Formation above. They are separated by an unconformity from the underlying Klimaki Group. We will focus our analysis on the Episkopi Formation. The thickness of the formation varies from $10 \mathrm{~m}$ (tectonically reduced) at Agios Nikolaos (Eastern part) to $100 \mathrm{~m}$ at Lehusis, and $120 \mathrm{~m}$ at Episkopi section in the West.

The lower part is mainly composed of conglomerate lenses with dolomitic pebbles from the underlying Marmari Formation, or of thin bedded dolomicrite. The lower $90 \mathrm{~m}$ of the Episkopi Formation are thickly bedded and consist of high energy bioclastic lime packstone-grainstones with silicification, rich in calcareous algae, small foraminifers and fragments of brachiopods, bryozoans and corals. The following $55 \mathrm{~m}$ of stratified limestones are characterized by flat to round chert

* In Sohn (1978): USNM locality 9260: southern side of the Island of Hydra, just off the Argolian coast, Greece (see Grant, 1972, pp. 214, 215, for description), about $0.5 \mathrm{~km}$ south of the village of Episkopi. Weathered limestone blocks containing silicified fossils on stratigraphically of two benches. USNM locality 9262: same Island as above, about $3 \mathrm{~km}$ north-northeast of Episkopi. Limestone blocks and pieces from a bed about $1.2 \mathrm{~m}$ thick. 


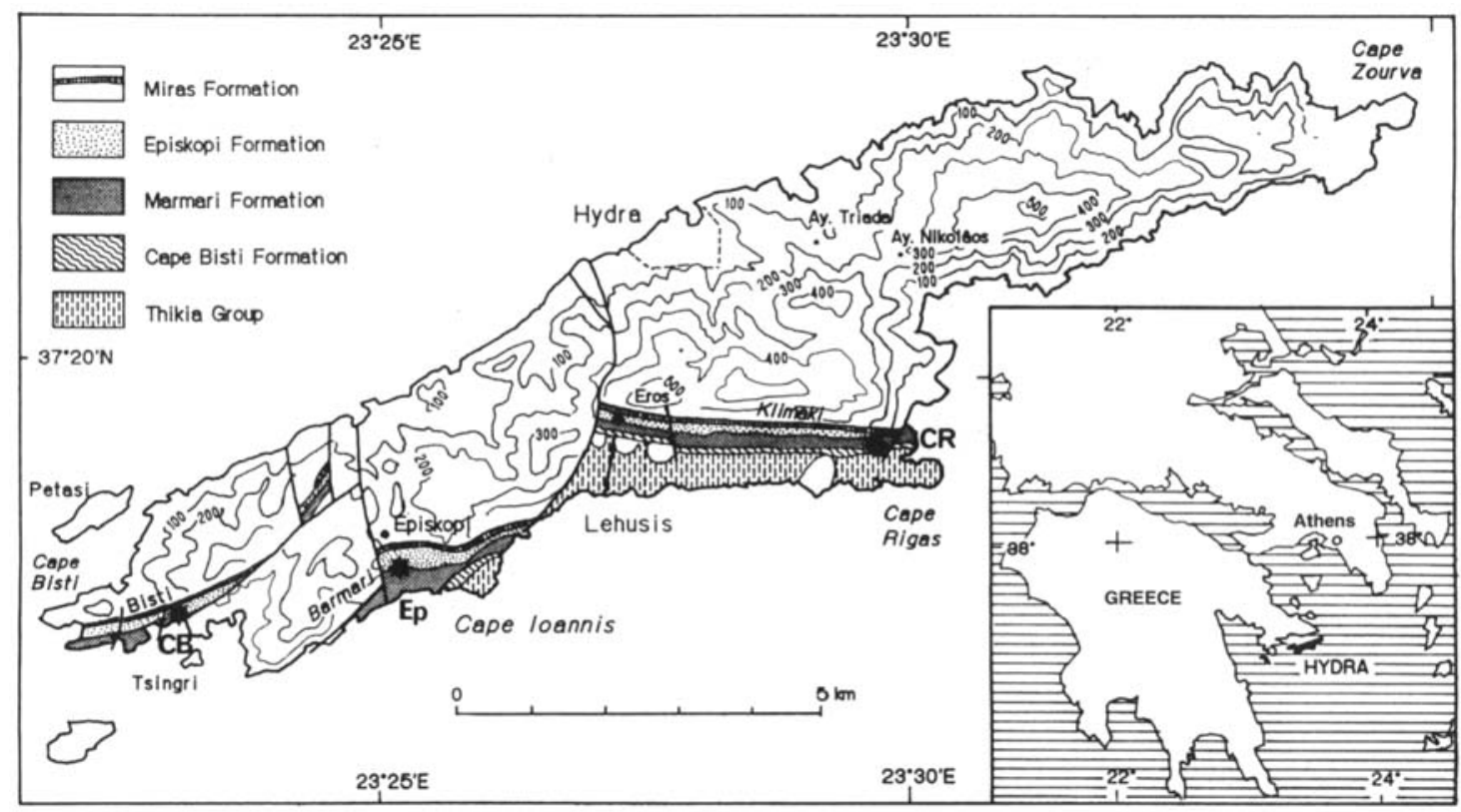

Fig. 1. Schematic geological map of Hydra Island (after Grant et al., 1991) showing localities and sections sampled (stars): CB: Cape Bisti, Ep: Episkopi, CR: Cape Rigas.

pebbles in fine bioclastic lime packstone with sponge spicules, crinoids, calcareous algae and foraminifers. The cherty limestone is overlain by $10 \mathrm{~m}$ of grey nodular lime wackestone followed by $30 \mathrm{~m}$ of well bedded lime packstone-wackestone with marly interbeds. Sponges, crinoids, bryozoans, foraminifers and ostracods are associated with this facies which also contains the famous brachiopods localities of Grant (1995).

The shallow carbonate Episkopi Formation ends abruptly with algal limestones. The overlying Miras Formation is $c$. $30-$ $100 \mathrm{~m}$ thick, and consists of brown to dark red shales with various carbonate lenses or blocks. This terrigenous unit still contains Permian brachiopods and forams.

\section{OSTRACOD OCCURRENCE}

Few data are available on Permian ostracods from Greece. Two papers (Kornicker \& Sohn, 1976; Sohn, 1978) document Permian ostracods from Hydra Island. There are Thaumatomna piscifrons Kornicker \& Sohn, 1976 (type species of Thaumatomna Kornicker \& Sohn, 1976 - USNM locality 9260), Tribolbina doescheri Sohn, 1978 (localities 9260, 9262), Tribolbina aff. $T$. doescheri Kornicker \& Sohn (1976, p. 107) added to the description of the genus Thaumatomna the following: 'habitat: associated brachiopods, rare trilobite fragments, fusuline and others foraminiferids, as well as benthic ostracods in families including Bairdiidae, Amphissitidae, Kellettinidae, Roundyella Bradfield, 1935 (?Scrobiculidae), Hollinellidae and the presence of growth stages in many of the species indicate a normal marine shelf habitat'. They noted therefore the presence of different families without any species identification.

The ostracods described here occur in three main sections from the NE to the SW: Cape Rigas, Episkopi and Cape Bisti sections (Fig. 1). One sample of the Lehusis section (sample 48631) provides two species.

From 183 samples processed by hot acetolysis (Lethiers \&
Crasquin-Soleau, 1988) belonging to the four sections, only 39 samples contained ostracods. All the studied levels are well agecalibrated by foraminifera from the Late Asselian to Dorashamian (Grant et al., 1991). The distribution of the 66 ostracod species ( 34 genera) is given on a general statigraphic section of the Permian of Hydra (Fig. 3).

\section{SYSTEMATIC DESCRIPTIONS}

All the material is deposited in the collections of the Geological Museum of Lausanne, Switzerland (MGL).

L1: anterior lobe; L2: median lobe; L3: posterior lobe; S2: median sulcus; $L$ : length; $H$ : height.

Order Podocopida Müller, 1894

Suborder Podocopina Sars, 1866

Superfamily Bairdiacea Sars, 1888

Family Bairdiidae Sars, 1888

Genus Bairdia McCoy, 1844

Bairdia rigasensis Crasquin-Soleau n. sp.

(Pl.1, figs 1-5)

? 1982 Parurobairdia sp. Chen \& Shi: 135, pl. 8, figs 16-18.

Derivation of name. From Cape Rigas (Hydra Island), type locality.

Diagnosis. Carapace long and tapering; anterior border with small radius of curvature with maximum convexity located high; one straight ridge along ventral margin on each valve.

Types. Holotype: carapace MGL74389 (Pl. 1, fig.1); paratype: carapace MGL74390 (Pl. 1, fig. 2).

Type level. Sample 50148, Cape Rigas section, Hydra Island (Greece), Late Asselian-Early Artinskian.

Material. Eight complete carapaces.

Geographic and stratigraphic occurrences. Hydra Island, Cape Rigas section (sample 50148), Cape Rigas Formation, ? South China, Nantong, Mianyang, Late Asselian-Early Arkinskian, ?Late Permian. 


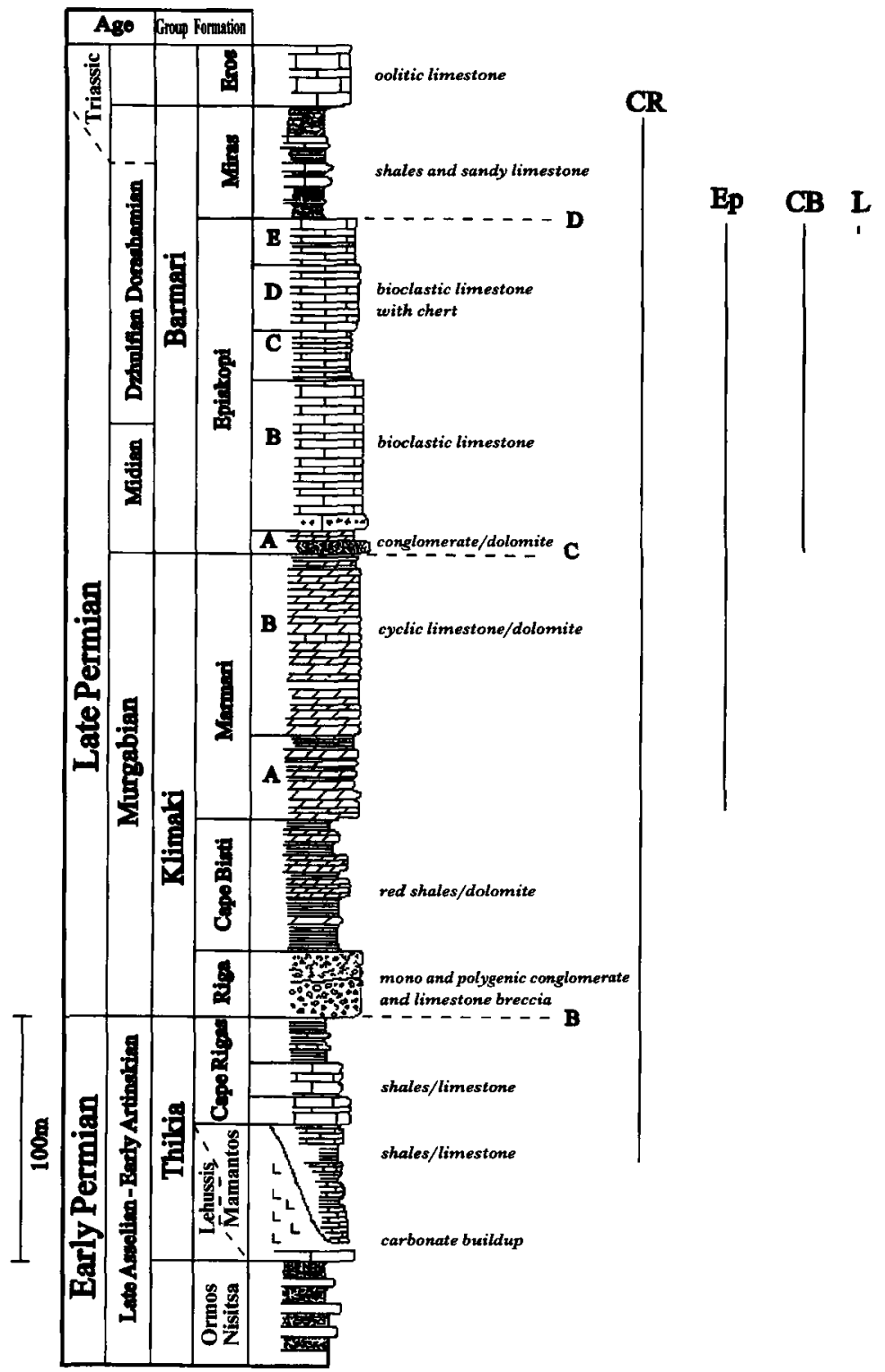

Fig. 2. Composite section of the Permian of Hydra Island (after Baud et al., 1991). B, C, D: events in Baud et al. (1991). CR: Cape Rigas section, Ep: Episkopi section, CB: Cape Bisti section, L: position of the sample with ostracods in Lehusis section.

Description. Carapace long, with anterior and posterior borders laterally flattened; left valve slightly overlaps the right one all around the carapace; dorsal border straight at the two valves; anterodorsal border straight to gently concave; anterior border with small radius of curvature, laterally flattened, maximum convexity located above mid-height, anteroventral border straight; ventral border gently concave, presence of a straight ventral ridge on each valve; posteroventral margin straight and long; posterior border tapering, strongly flattened laterally, maximum convexity located below lower third of height; posterodorsal border straight; angle between posterodorsal border and dorsal border (of right valve) $130^{\circ}$, between dorsal border and anterodorsal border $140^{\circ}$; maximum height located at $57 \%$ of length; carapace smooth.

Dimensions. $L=0.62-1.10 \mathrm{~mm}, H=0.25-0.58 \mathrm{~mm}$

Discussion. This species has a general outline close to that of Bairdia vyasovkensis Khivintseva, 1969 from the Kazanian of SW Urals, but that species has no ridge. This species has similar ventral ridges as in Bairdia praealiger Tkatscheva, 1975 (in Ivanova et al., 1975) from the Upper Carboniferous of Russian Platform, but here the ridges are straight and the valve overlap is less obvious.

The new species is tentatively put into synonymy with Parurobairdia sp. in Chen \& Shi (1982) from the latest Permian of South China. Indeed, this species appears to be identical, but the figures are poor and no material could be examined. 


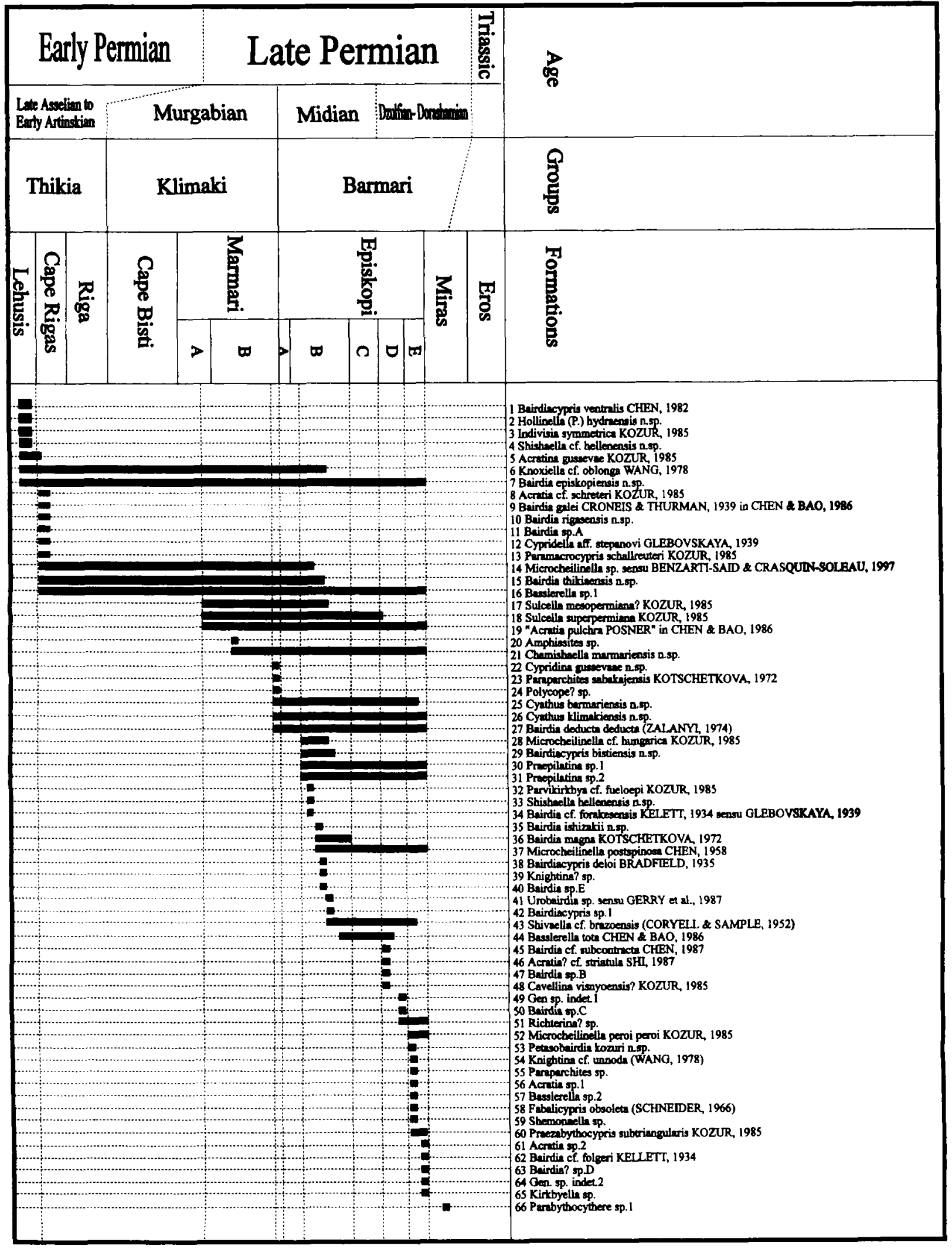

Fig. 3. Stratigraphic ranges of Permian ostracods of Hydra Island 


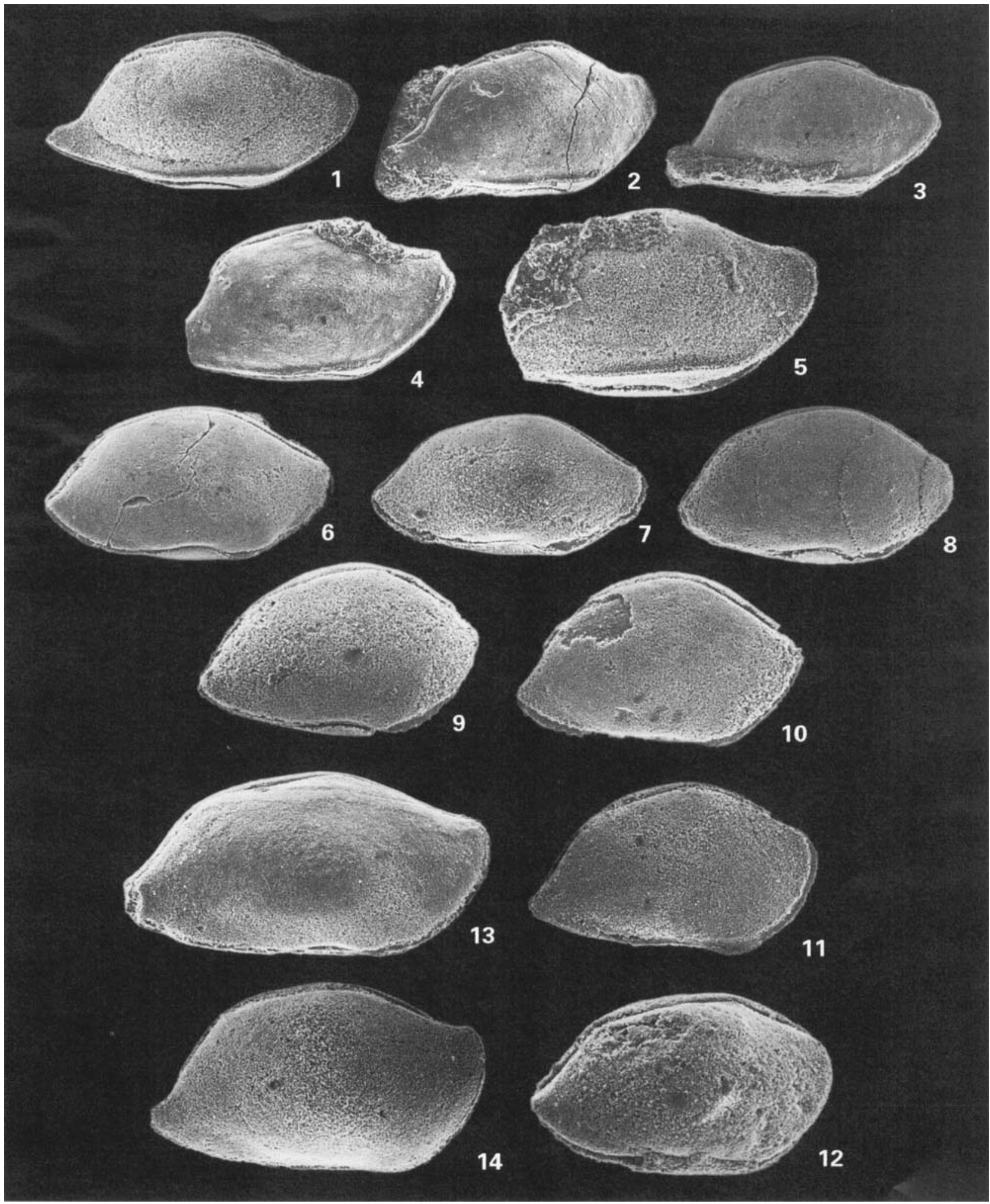

\section{Explanation of Plate 1}

figs 1-5. Bairdia rigaensis Crasquin-Soleau n.sp. (sample 50148). fig. 1: right lateral view, holotype, MGL74389, $\times 50$. fig. 2: right lateral view, paratype, MGL74390, $\times 50$. fig. 3: right lateral view, MGL74391, $\times 50$. fig. 4: right lateral view, MGL74423, $\times 50$. fig. 5: right lateral view, MGL74392, $\times 80$. figs 6-8. Bairdia episkopiensis Crasquin-Soleau n.sp. fig. 6: right lateral view, holotype, MGL74393, x50, sample 50148. fig. 7: right lateral view, paratype, MGL74394, $\times 50$, sample 50148. fig. 8: right lateral view, paratype, MGL74395, $\times 70$, sample 50146. fig. 9-12. Bairdia thikiaensis Crasquin-Soleau n.sp. fig. 9: right lateral view, paratype, MGL74396, $\times 90$, sample 50148. fig. 10: right lateral view, paratype, MGL74397, $\times 70$, sample 50148. fig. 11: right lateral view, holotype, MGL 74398, $\times 60$, sample 50148. fig. 12: right lateral view, MGL74399, $\times 70$, sample 90-46. fig. 13. Bairdia sp. A, right lateral view, MGL74400, $\times 70$, sample 50148. fig. 14. Bairdia sp. B, right lateral view, MGL74401, $\times 50$, sample 48585. 
Bairdia episkopiensis Crasquin-Soleau n. sp.

(Pl. 1, fig. 6-8)

Derivation of name. From the Episkopi section, SW Hydra Island.

Diagnosis. Anterior border with small radius of curvature, flattened laterally; anteroventral border concave; posterior border flattened only in its ventral part.

Types. Holotype, carapace MGL74393 (Pl. 1, fig. 6); paratypes, two carapaces MGL74394 and MGL74395 (Pl. 1, fig. 7-8).

Type level. Sample 50148, Cape Rigas section, Hydra Island (Greece), Late Asselian-Early Artinskian.

Material. 10 complete carapaces

Geographic and stratigraphic occurrences. Hydra Island, Cape Rigas section, Lehusis Formation (sample 50146), Cape Rigas Formation (sample 50148), Episkopi section, Episkopi Formation, (sample 90-46); Late Asselian-Midian.

Description. Carapace smooth; left valve slightly overlaps the right one on all the borders; dorsal border gently convex on both valves; anterodorsal border nearly straight on both valves; anterior border with small radius of curvature, maximum convexity located at mid-height, flattened laterally; anteroventral border concave on both valves; ventral border concave; posteroventral border convex; posterior border sharp, maximum convexity located at $60 \%$ of height, flattened laterally only in its ventral part; posterodorsal border straight on both valves; angle between posterodorsal border and dorsal border $=145^{\circ}$, between dorsal border and anterodorsal border $=135^{\circ}$, maximum height located just in front of mid-length.

Dimensions. $L=0.56-1.02 \mathrm{~mm}, H=0.32-0.57 \mathrm{~mm}$.

Discussion. This species can be compared to Bairdia subhassi Beloussova, 1965 from the Upper Permian-Dzulfian-Dorashanian from Transcaucasus, which has a longer posterior border, an anterior border with a smaller radius of curvature and a maximum convexity located higher.

\section{Bairdia thikiaensis Crasquin-Soleau n.sp.} (Pl. 1, figs 9-12)

Derivation of name. From the type level of the Thikia Group. Diagnosis. Carapace short with truncated anteroventral border, posterior border fine with maximum convexity located very low, and anterior border with maximum convexity located high.

Types. Holotype, carapace MGL74398 (Pl. 1, fig. 11); paratypes, two carapaces MGL74396 and MGL394397 (Pl. 1, figs 9-10).

Type level. Sample 50148, Cape Rigas section, Hydra Island (Greece), Late Asselian-Early Artinskian.

Material. Seven complete carapaces and some fragments.

Geographic and stratigraphic occurrences. Hydra Island, Cape Rigas section, Cape Rigas Formation (sample 50148), Cape Bisti section, Episkopi Formation (sample 90-31), Late AsselianMidian.

Description. Carapace short $(H / L=0.61)$, flattened laterally in anterior and posterior parts; dorsal border straight in right valve, slightly convex in left valve; anterodorsal dorsal border almost straight in both valves; anterior border with very small radius of curvature, with maximum convexity located high (at $40 \%$ of height), anteroventral border straight to gently convex; ventral border concave on right valve, nearly straight on left one; posteroventral border almost straight, posterior end in prolongation of it, posterior border with small radius of curvature, maximum convexity located low (at $85 \%$ of height); posterodorsal border straight on both valves; moderate overlap of left valve on right one all around the carapace; carapace slightly flattened laterally in anterior and posterior parts.

Dimensions. $L=0.54-0.86 \mathrm{~mm} ; H=0.32-0.51 \mathrm{~mm}$.

Discussion. This species is similar to Bairdia altaricus Chen, 1958 from the Lower Permian of South China but is distinguished by its more truncated anteroventral border, a reduced overlap, especially dorsally and a thinner carapace.

\section{Bairdia ishizakii Crasquin-Soleau n.sp.} (Pl. 2, figs 1-6)

Derivation of name. In honor of Dr Ishizaki, Japan.

Diagnosis. Strong overlap of left valve over right one; presence of a large node in central part of each valve.

Types. Holotype, carapace MGL774403 (Pl. 2 fig. 2); paratypes, two carapaces MGL74405 and MGL74407 (Pl. 2, fig. 6).

Type level. Sample 48539, Hydra Island (Greece), Cape Rigas section, Episkopi Formation, Midian-Dorashamian.

Material. Two complete carapaces, three broken carapaces, five valves.

Geographic and stratigraphic occurrences. Hydra Island, Cape Rigas section (sample 48531), Episkopi section (sample 90-46), Episkopi Formation, Midian-Dorashamian.

Description. Carapace massive with very strong overlap of left valve over the right one all around the shell. Left valve: dorsal border convex, anterodorsal border strongly concave, anterior border with small radius of curvature (dorsal part almost horizontal and ventral part nearly vertical), maximum convexity located high; anteroventral border weakly convex to straight; ventral border straight to feebly convex; posteroventral border straight; posterior border rounded with small radius of curvature; posterodorsal border concave. Right valve: dorsal border strongly convex; anterodorsal border nearly straight passing to anterior border which is tapering with very small radius of curvature; anteroventral border convex; ventral border

Explanation of Plate 2

figs 1-6. Bairdia ishizakii Crasquin-Soleau n.sp. fig.1: right lateral view of broken carapace, MGL74402, $\times 50$, sample 90-46. fig. 2: right lateral view, holotype, MGL74403, $\times 50$, sample 48539. fig. 3: left lateral view of broken carapace, MGL74404, $\times 60$, sample 48539. fig. 4: right lateral view of isolated valve, paratype, MGL74405, $\times 50$, sample 48539. fig. 5: left lateral view of isolated valve, MGL74406, $\times 50$, sample 48539. fig. 6: dorsal view, paratype, MGL74407, $\times 50$, sample 48539. figs 7-10. Petasobairdia kozuri Crasquin-Soleau n.sp. fig.7. right lateral view, holotype, MGL74408, $\times 60$, sample 48587. fig. 8: right lateral view, paratype, MGL74409, $\times 60$, sample 90-59. fig. 9: left lateral view, MGL74410, $\times 70$, sample 90-59. fig. 10: left lateral view, MGL74411, $\times 60$, sample 90-59. fig. 11. Bairdia sp.C, right lateral view, MGL74412, $\times 35$, sample 50224. fig. 12. gen. sp. indet., left lateral view?, MGL74413, ×50, sample 90-59. fig. 13. Cypridella aff. stepanovi Glebovskaya, 1939, right ventro-lateral view, MGL74414, $\times 50$, sample 50148. fig. 14-15. Bairdia? sp.D (sample 90-59). fig. 14: left lateral view, MGL74415, $\times 35$. fig. 15 . right lateral view, MGL74416, $\times 50$. 


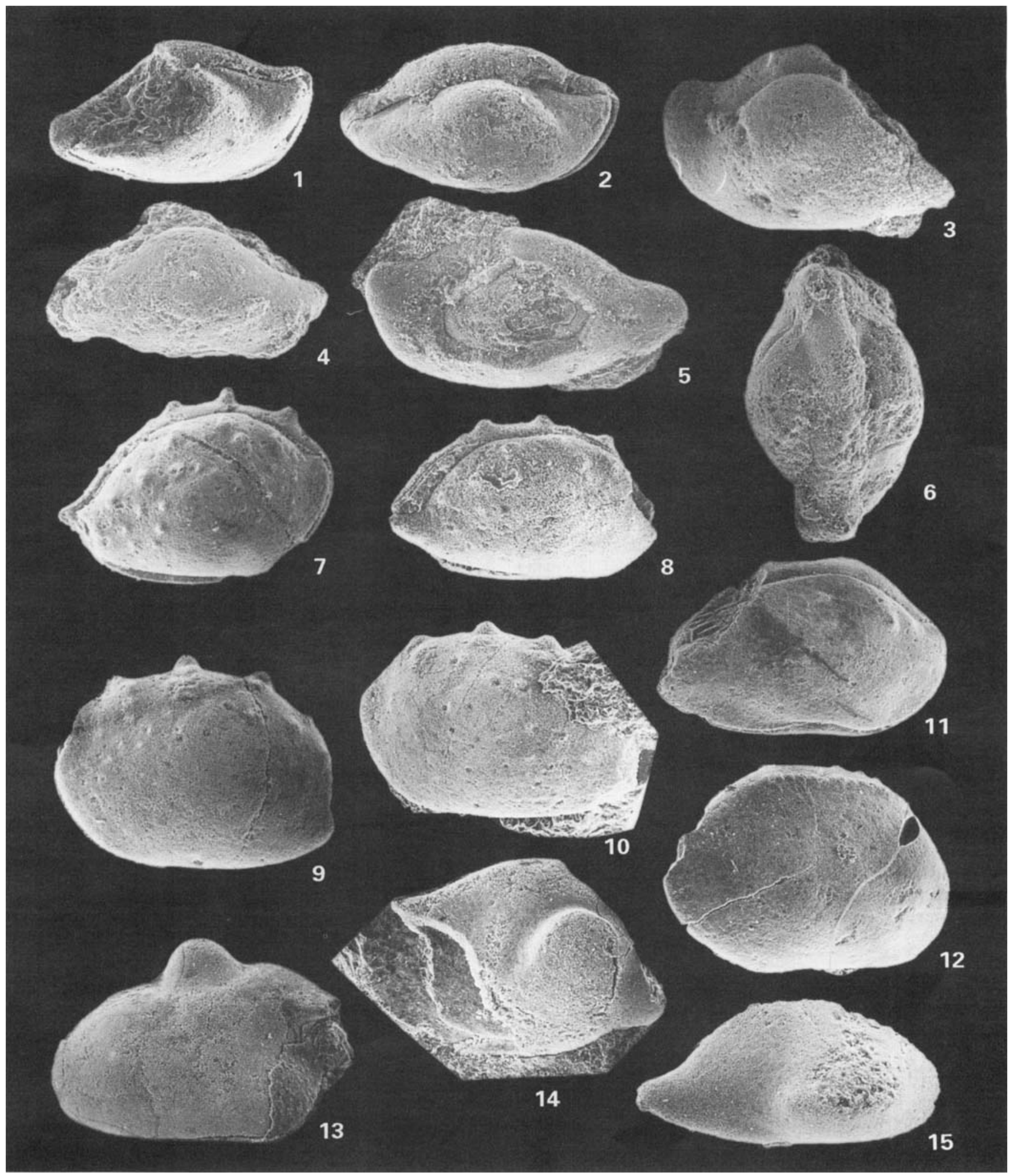


straight; posteroventral border straight to gently convex; posterior border tapered; posterodorsal border concave. On both valves: carapace strongly flattened laterally in anterior and posterior parts; presence of large node in central part of valves; in dorsal view, carapace is very thick with strong overlap of left valve. Carapace smooth.

Dimensions. $L=0.96-1.14 \mathrm{~mm} ; H=0.56-0.62 \mathrm{~mm}$.

Discussion. Bairdia ishizakii n.sp. is similar to Spinobairdia sp. described by Ishizaki (1964) from the Middle Permian Iwaizaki Limestone (NW Japan) but the latter species has a small central node and a straight dorsal border.

Genus Petasobairdia Chen, 1982

Petasobairdia kozuri Crasquin-Soleau n.sp. (Pl. 2, figs 7-10)

Derivation of name. In honor of Dr Heinz Kozur, Hungary. Diagnosis. Presence of three nodules on dorsal border of left valve.

Types. Holotype, carapace MGL74408 (Pl. 2 fig. 7); paratype carapace MGL74409 (Pl. 2, fig. 8).

Type level. Sample 48587, Hydra Island (Greece), Episkopi section, Episkopi Formation, Dzulfian-Dorashamian.

Material. Three complete carapaces, two isolated left valves, three isolated right valves and some fragments.

Geographic and stratigraphic occurrences. Hydra Island, Episkopi section (sample 48587, 90-59), Episkopi section, DzulfianDorashamian.

Description. Carapace short with a few large punctue; left valve: outline round except in posterior part where posterior border is very fine; presence of three nodes on dorsal border; right valve: outline rounded except in anterior and posterior parts; anterior border horizontal in dorsal part and with small radius of curvature, posterior border very tapered; no nodes. On both valves: carapace strongly flattened laterally in anterior and posterior parts. Left valve overlaps the right valve all around the carapace with maximum in dorsal part.

Dimensions. $L=0.72-0.88 \mathrm{~mm} ; H=0.50-0.58 \mathrm{~mm}$ (without nodes).

Discussion. This new species can be compared to Petasobairdia bidentata Kozur, 1985 from the Dzhulfian of North Hungary which has two spines on dorsal border, but that species has a more triangular outline (probably caused by poor preservation?).
Genus Bairdiacypris Bradfield, 1935

Bairdiacypris bistiensis Crasquin-Soleau n.sp.

(Pl. 3, figs 11-12)

Derivation of name. From the Cape Bisti section.

Diagnosis. Carapace regularly convex at dorsal border of left valve, maximum height located at mid-length.

Types. Holotype, carapace MGL74420 (Pl. 3 Fig. 11); paratype, carapace MGL74421 (Pl. 3, Fig. 12).

Type level. Sample 90-49, Hydra Island (Greece), Episkopi section, Episkopi Formation, Midian-Dzulfian.

Material. Ten complete carapaces.

Geographic and stratigraphic occurrences. Hydra Island, Episkopi section (sample 90-46, 90-49), Cape Bisti section (sample 90-17), Episkopi Formation, Midian-Dzulfian.

Description. Dorsal outline of left valve regularly convex, at right valve dorsal, anterodorsal and posterodorsal borders straight; carapace flattened laterally in anterior and posterior parts; ventral border straight at left valve, concave at right one. Maximum height at mid-length.

Dimensions. $L=0.65-1.08 \mathrm{~mm} ; H=0.36-0.54 \mathrm{~mm}$.

Discussion. This species is close to Bairdiacypris deloi Bradfield, 1935 from the Upper Carboniferous-Upper Permian of USA, Tunisia, South China (?), but differs in that the dorsal border of the left valve is more convex and the maximum height is located in the central part of the carapace. Bairdiacypris bistiensis Crasquin-Soleau n.sp. can also be compared to Bairdiacypris haqanaensis Gerry \& Honingstein, 1987 from the Late Permian of Israel. This last species has an anterior border with a larger radius of curvature, a convex hinge line and a carapace that is not flattened laterally.

Order Palaeocopida Henningmöen, 1953

Suborder Beyrichicopina Scott, 1961

Superfamily Aparchitacea Jones, 1901

Family Aparchitidae Jones, 1901

Genus Cyathus Roth \& Skinner, 1930

Remark. Guan (1978) described the genus Sinocoelonella which is close to Cyathus Roth \& Skinner, 1930 in outline but with lateral ridges and without a low velate structure along the free margin. Chen \& Shi (1982), Chen \& Bao (1986) and Shi \& Chen (1987) place Sinocoelonella Guan, 1978 in the genus Cyathus Roth \& Skinner, 1930. Because of the nearly symmetric

fig. 1. Acratina gussevae Kozur, 1985, left lateral view, MGL74360, $\times 90$, sample 50146. fig. 2. Acratia sp.2, right lateral view, MGL74361, $\times 60$, sample 90-11. figs 3, 5-6, 9. Sulcella mesopermiana Kozur, 1985. fig. 3: left lateral view, MGL74362, $\times 60$, sample 90-43. fig. 5: left lateral view, MGL74363, $\times 60$, sample 48570. fig. 6: left lateral view, MGL74364, ×60, sample 48570. fig. 9: right lateral view, MGL74365, $\times 60$, sample 90-46. fig. 4. Acratia cf. schreteri Kozur, 1985, left lateral view, MGL74418, $\times 50$, sample 50148. figs 7-8, 10. Praezabythocypris subtriangularis Kozur, 1985. fig. 7: right lateral view, MGL74366, $\times 120$, sample 90-59. fig. 8: right lateral view, MGL74419, $\times 80$, sample 50233. fig. 10: right lateral view, MGL74367, $\times 80$, sample 90-59. figs 11-12. Bairdiacypris bistiensis Crasquin-Soleau n.sp. (sample 90-49). fig. 11: holotype, right lateral view, MGL74420, $\times 50$. fig. 12: paratype, right lateral view, MGL74421, $\times 50$. fig.13. Bairdiacypris ventralis Chen, 1982 (only pl. 12, figs 25, 26, 29), right lateral view, MGL74422, $\times 50$, sample 50146. fig. 14. Bairdiacypris sp.1, right lateral view, MGL74368, $\times 60$, sample $90-49$. fig. 15. Bairdiacypris deloi Bradfield, 1935 , right lateral view, MGL74369, $\times 50$, sample 90-46. figs 16-17. 'Acratia pulchra Posner' in Chen \& Bao, 1986 (species figured by Chen \& Bao, 1986 but not Acratia pulchra Posner). fig.16. right lateral view, MGL74370, $\times 70$, sample 90-59. fig. 17: right lateral view, MGL74371, $\times 60$, sample 48570 . fig. 18 . Bairdia galei Croneis \& Thurman, 1939 in Chen \& Bao, 1986, right lateral view, MGL74372, ×80, sample 50148. 

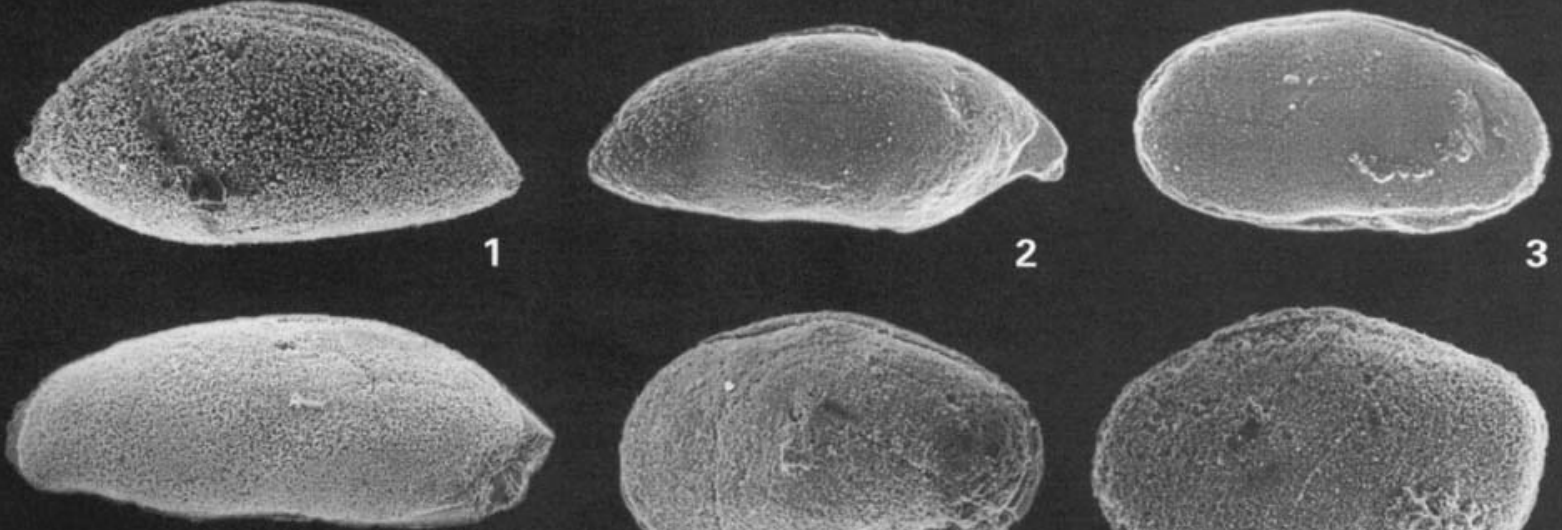

4
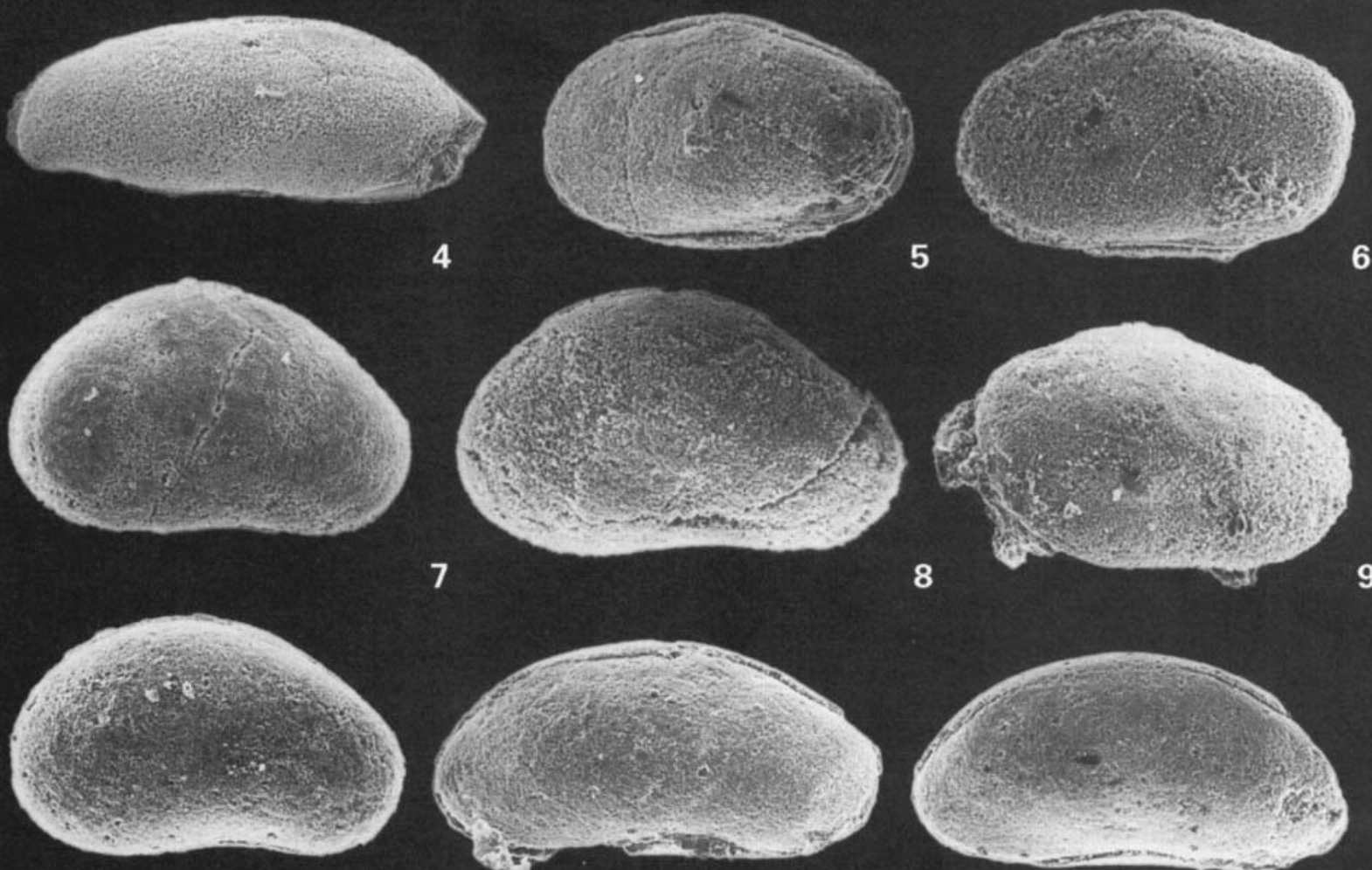

10
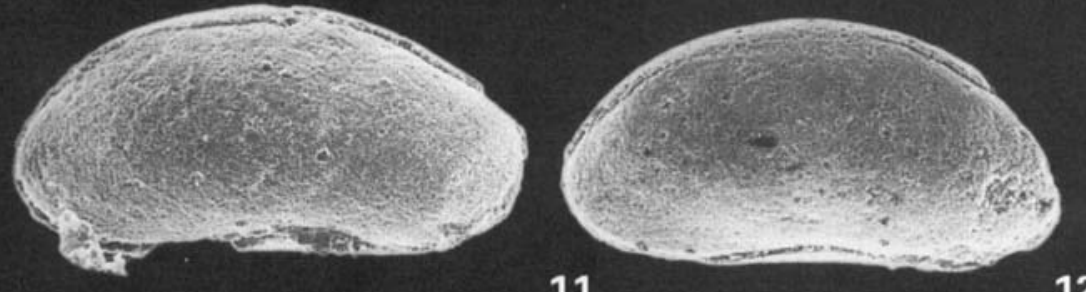

11

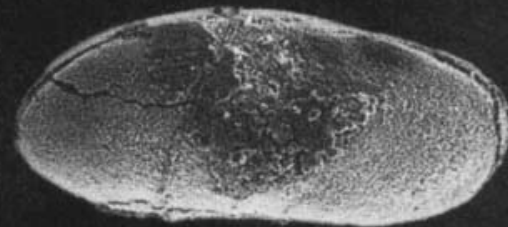

13
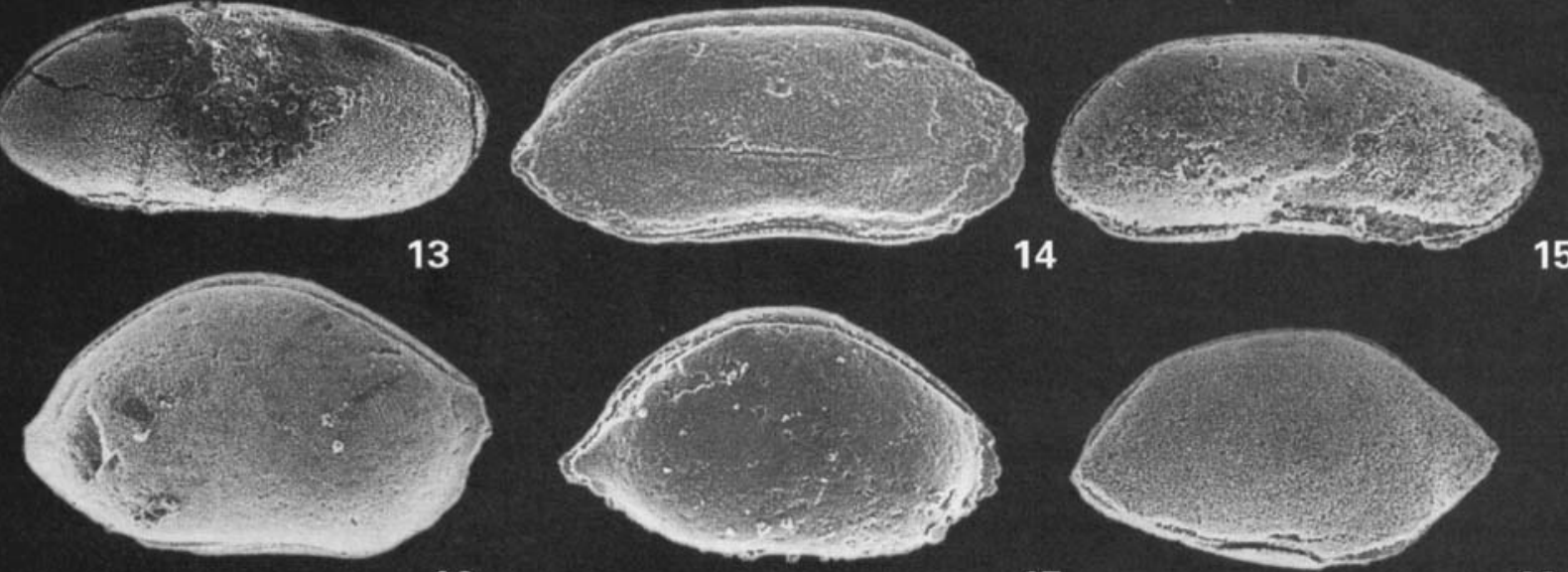

17

18 
convexity of the carapace, orientation is difficult to ascertain. Kozur (1991a) published a long and very interesting discussion (pp. 16-17) about this problem and its systematic implications. The Chinese authors regard the strongly convex margin as being the ventral one. Kozur (1991a) considered that the convex margin is, in fact, the dorsal margin. After substantial observation of the specimens found here, the authors follow the Chinese procedure. Prof. F. Lethiers (Université P. et M. Curie, Paris, pers. comm.) thinks that these two genera are the same (Cyathus). In accordance with him, we consider that the lateral ornamentation is an insufficient character with which to separate the two genera because the lack of ridges is often the result of fossilization, and the velate structure is low and its observation is not always possible. The genus Sinocoelonella is a junior synomym of Cyathus.

\section{Cyathus barmariensis Crasquin-Soleau n.sp.}

$$
\text { (Pl. 4, figs 4-7) }
$$

Derivation of name. From the Barmari Group which include the type level.

Diagnosis. Carapace assymetrical without ridges, very fine linear punctuation parallel to dorsal and ventral margins.

Types. Holotype, carapace MGL74318 (Pl. 4, fig. 4); paratype, carapace MGL74319 (Pl. 4, fig. 7).

Type level. Sample 90-49, Hydra Island (Greece), Episkopi section, Episkopi Formation, Midian-Dzulfian.

Material. Ten complete carapaces.

Geographic and stratigraphic occurrences. Hydra Island, Episkopi section, Marmari Formation (sample 90-43), Episkopi Formation (samples 90-46, 90-49, 90-58); Cape Bisti section, Episkopi Formation (samples 90-17, 90-18, 90-19), Late Murgabian-Dorashamian.

Description. Dorsal border convex in central part and gently concave at its two extremities; cardinal angles very obtuse; anterior border with great radius of curvature, maximum convexity located at $42-44 \%$ of height; ventral border regulary convex with maximum height located at mid-length or slightly in front of mid-height; posterior border with small radius of curvature, maximum convexity located at $35-40 \%$ of height; carapace flattened laterally at anterior and posterior parts; in largest forms flattening also in ventral part; dorsal borders overhang hinge line on both valves but more strongly for the right one, right valve slightly overlaps the left one on free margins; surface with a very fine punctation, which seems to be organized along lines parallel to dorsal and ventral borders. Dimensions. $L=0.55-0.76 \mathrm{~mm} ; H=0.36-0.45 \mathrm{~mm}$.
Discussion. The general outline of Cyathus barmariensis Crasquin-Soleau n.sp. is similar to Cyathus formosa Shi, 1982 from the latest Permian from South China (in Chen \& Shi, 1982), but our species lacks the primary ridges.

\section{Cyathus klimakiensis Crasquin-Soleau n.sp.} (Pl. 4, figs 8-9)

Derivation of name. From the Klimaki Group which include the type level.

Diagnosis. Carapace symmetrical with fine ridges and organized punctue.

Types. Holotype, carapace MGL74322 (Pl. 4, fig. 8); paratype, carapace MGL74323 (Pl. 4, fig. 9).

Type level. Sample 50181, Hydra Island (Greece), Episkopi section, Marmari Formation, Late Murgabian.

Material. Three complete carapaces and some fragments.

Geographic and stratigraphic occurrences. Hydra Island, Episkopi section (sample 50181), Marmari Formation, Late Murgabian.

Description. Carapace almost symmetrical in lateral view, posterior border with a radius of curvature slightly smaller than anterior one; maximum height located at mid-length; anterior and posterior parts of dorsal border distinctly concave; presence of numerous fine ridges parallel to the ventral border, very fine punctation between them.

Dimensions. $L=0.55-0.58 \mathrm{~mm} ; H=0.32-0.35 \mathrm{~mm}$.

Discussion. The new species differs from Cyathus barmariensis Crasquin-Soleau n.sp. by the presence of fine ridges and a more symmetrical carapace in lateral view. In general outline, it is similar to Sinocoelonella caperatus Guan, 1978 from the Lower Permian of South China, but here it lacks the coarse lateral ridges. Cyathus barmariensis Crasquin-Soleau n.sp. is also close to Cyathus ulrichi sensu Ivanov, 1965 from the upper part of Lower Permian of the Donetz (Ivanov, 1965) and of Guatemala (Lethiers et al., 1995). The species described by Ivanov (1965) is more elongated.

Superfamily Hollinacea Swartz, 1936

Family Hollinellidae Bless \& Jordan, 1971

Genus Hollinella Coryell, 1928 emend. Kellett, 1929

Subgenus Hollinella (Praehollinella) Bless \& Jordan, 1971

Hollinella (Praehollinella) hydraensis Crasquin-Soleau n.sp.

(PI. 5, Figs 1-7)

Derivation of name. From Hydra Island.

\section{Explanation of Plate 4}

figs 1-3. Sulcella superpermiana Kozur, 1985. fig: 1: right lateral view, MGL74315, $\times 50$, sample 50176. fig. 2: left lateral view, MGL74316, $\times 50$, sample 90-150. fig. 3: right lateral view, MGL74317, $\times 70$, sample 48585. figs 4-7. Cyathus barmariensis Crasquin-Soleau n.sp. fig. 4: left lateral view, holotype, MGL74318, $\times 70$, sample 90-49. fig. 5: left lateral view, MGL74319, $\times 90$, sample 90-46. fig. 6: right lateral view, MGL74320, $\times 80$, sample 90-46. fig. 7: left lateral view, paratype, MGL74321, $\times 90$, sample 90-49. figs 8-9. Cyathus klimakiensis Crasquin-Soleau n.sp. (sample 50181). fig. 8: left lateral view,holotype, MGL74322, $\times 80$. fig. 9: left lateral view, paratype, MGL74323, $\times 100$. fig. 10. Indivisia symmetrica Kozur, 1985, right lateral view, MGL74324, $\times 100$, sample 50146. fig. 11. Shivaella cf. brazoensis (Coryell \& Sample, 1932), left lateral view, MGL74325, $\times 80$, sample 9049. figs 12, 14-15. Chamishaella marmariensis Crasquin-Soleau n.sp. fig. 12: right lateral view, holotype, MGL74326, $\times 90$, sample 90-40. fig. 14: right lateral view, MGL74327, $\times 110$, sample 48585. fig. 15: right lateral view, paratype, MGL74328, $\times 100$, sample 90-59. fig. 13. Shishaella cf hellenensis Crasquin-Soleau n.sp., right lateral view, MGL74329, $\times 60$, sample 50146. 

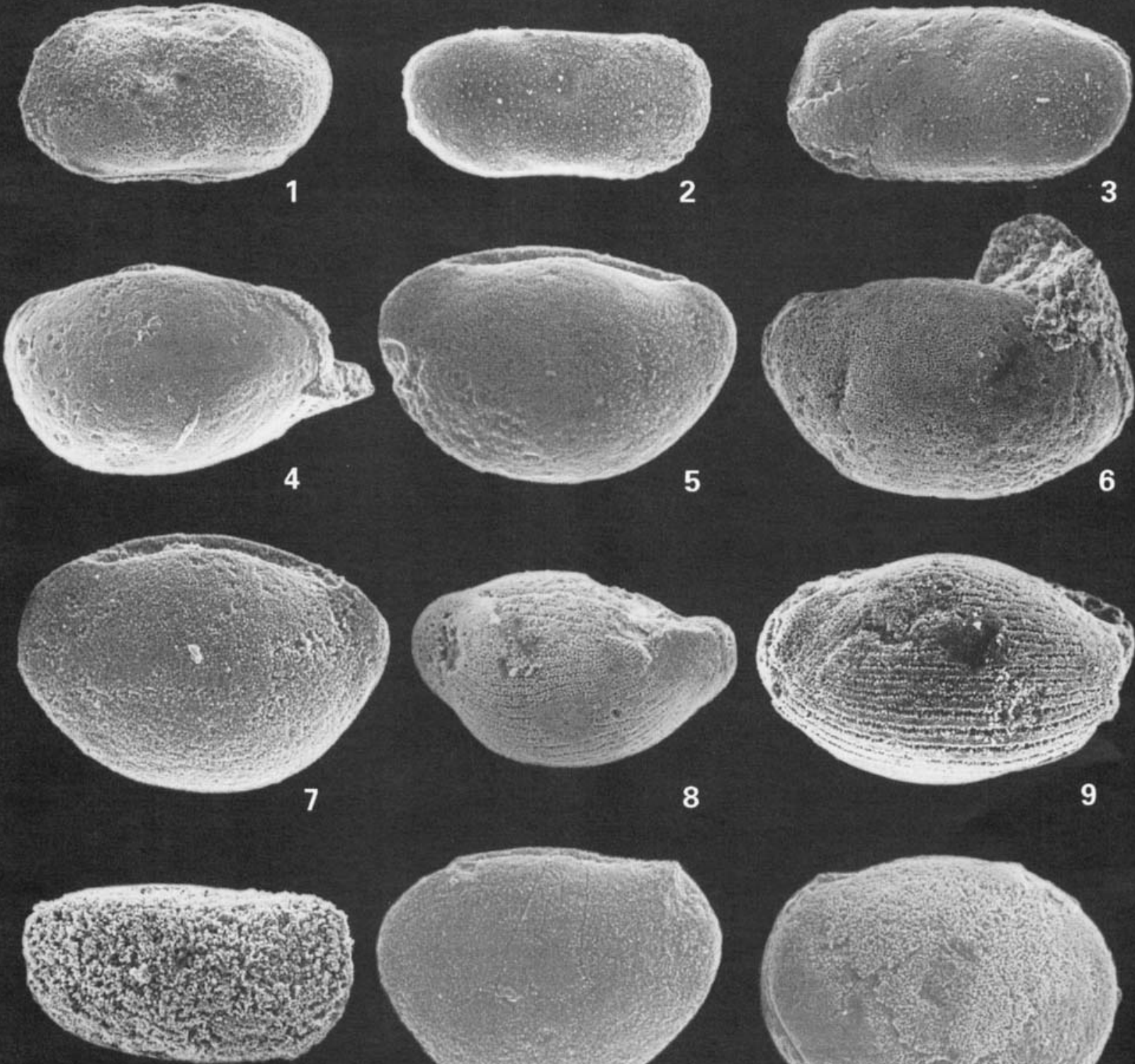

10
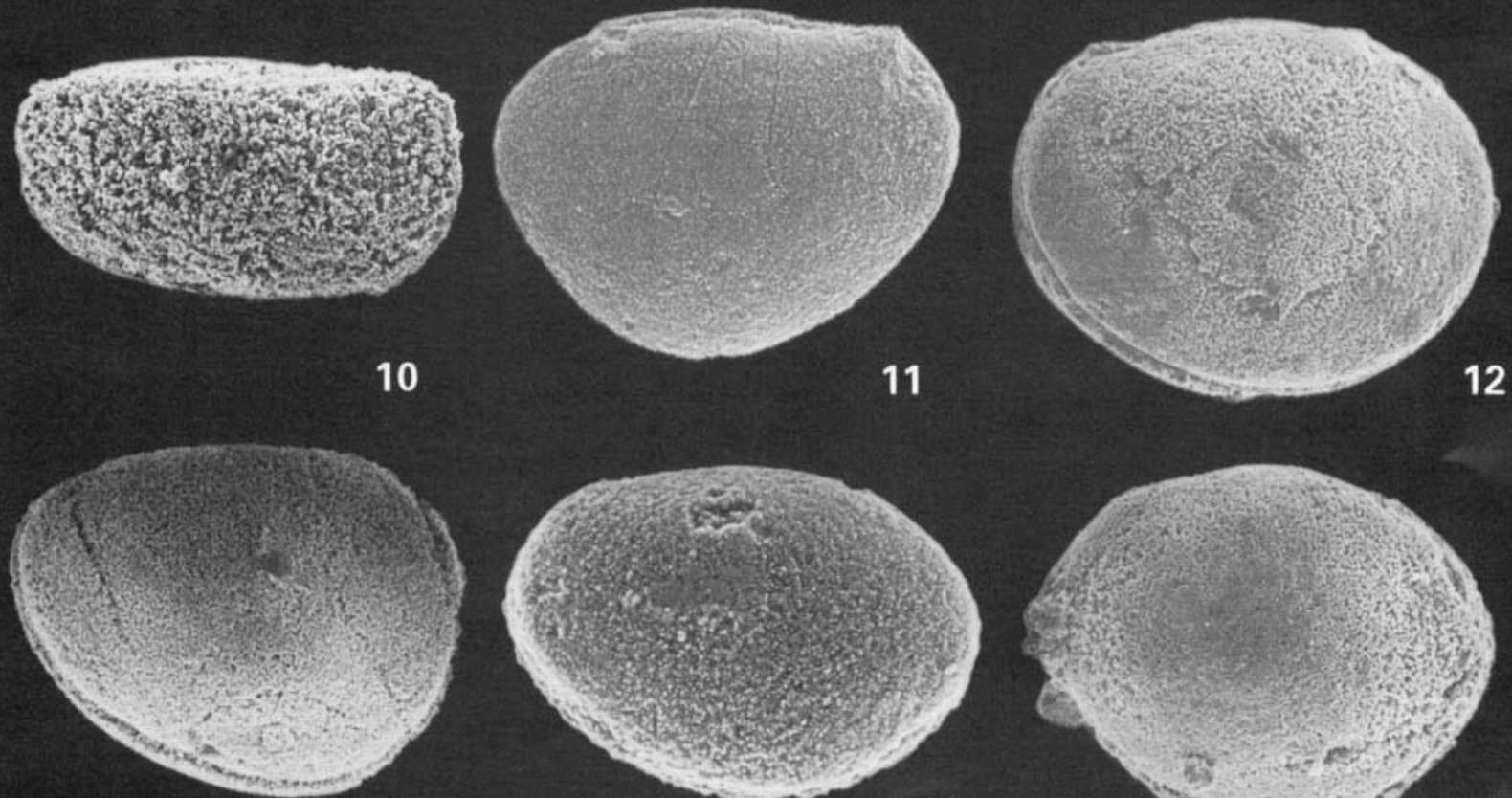

13
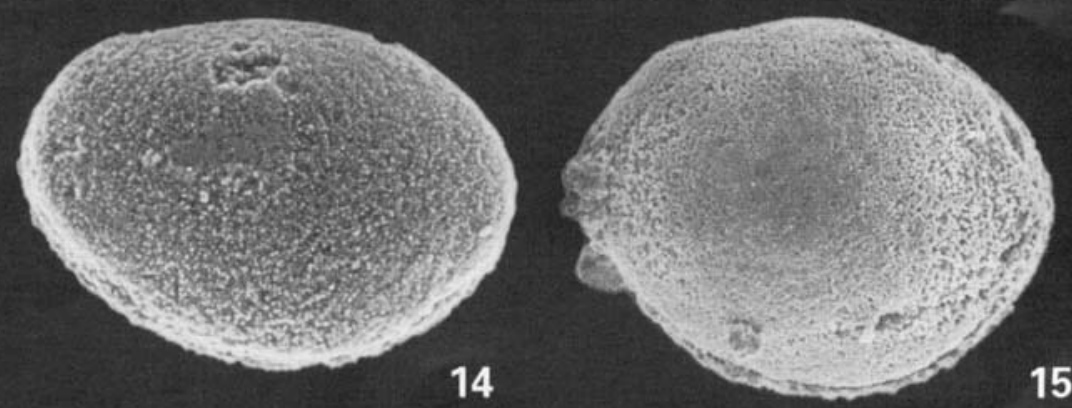


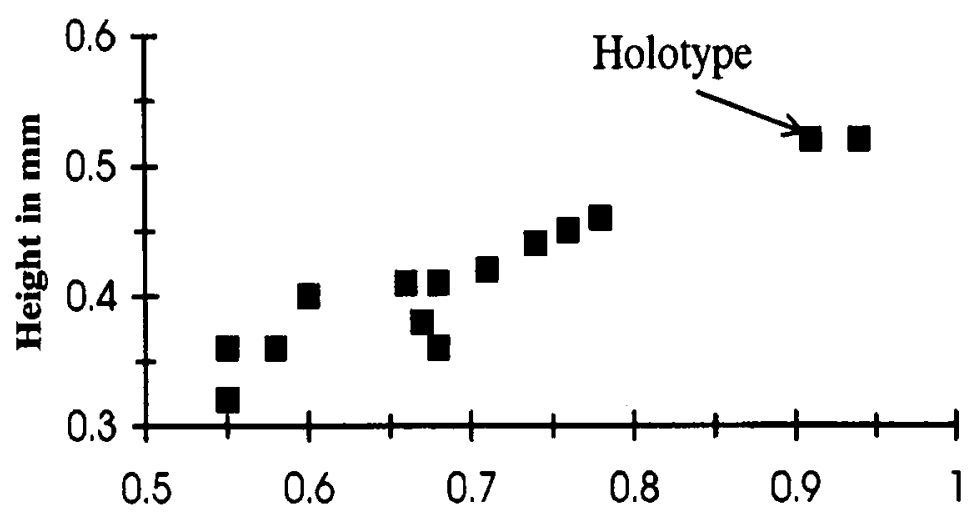

Length in $\mathbf{m m}$

Fig. 4. Size dispersion diagram (height / length) of Hollinella (P.) hydraensis n.sp. Lehusis formation (sample 50146), Cape Rigas section.

Diagnosis. Posterior cardinal angle close to $90^{\circ}$, ventral lobe fused with posterior lobe (L3), fringe smooth.

Types. Holotype, carapace MGL74301 (Pl. 5, fig. 1); paratypes, two carapaces MGL74302 and MGL74305 (P1. 5, figs 3 and 5. Type level. Sample 50146, Hydra Island (Greece), Cape Rigas section, Lehusis Formation, Late Asselian-Early Artinskian.

Material. Seventeen complete carapaces and three broken carapaces.

Geographic and stratigraphic occurrences. Hydra Island, Cape Rigas section (sample 50146), Lehusis Fomation, Late AsselianEarly Artinskian.

Description. Dorsal border long and straight; anterior cardinal angle $=110-120^{\circ}$; posterior cardinal angle $90^{\circ}$; anterior border with a very large radius of curvature, maximum convexity at mid-height or slightly below; L1 not visible; L2 distinct in its posterior part; S2 deep and long; L3 large and round fused with ventral lobe, the latter particulary visible in adult forms; fringe smooth in adults form, absent in instars; surface smooth; some specimens have two to five small nodes on the dorsal part of L3. Dimensions. $L=0.52-0.96 \mathrm{~mm} ; H=0.32-0.52$ (without L3); see Fig. 4.

Discussion. Our species is closed to Hollinella (P.) emaciata (Ulrich \& Bassler, 1906) from the Lower Permian of Kansas, USA. In our species, the cardinal angles are less obtuse which tend to affect the lateral outline of the carapace.

Suborder unknown

Superfamily Paraparchitacea Scott, 1959
Family Paraparchitidae Scott, 1959

Genus Shishaella Sohn, 1971

Shishaella hellenensis Crasquin-Soleau n.sp.

(P1. 6, figs 4-5)

Derivation of name. From Hellenos meaning Greece.

Diagnosis. Anterior border with large radius of curvature and maximum convexity located low; small spine in posterior cardinal angle of right valve, in prolongation presence of a dorsal shoulder.

Types. Holotype, carapace MGL74333 (Pl. 6, fig. 4); paratype, carapace MGL74334 (Pl. 3, fig. 5).

Type level. Sample 90-46, Hydra Island (Greece), Episkopi section, Episkopi Formation, Midian.

Material. Five carapaces and some fragments

Geographic and stratigraphic occurrences. Hydra Island, Episkopi section (sample 90-46), Episkopi Formation, Midian.

Description. Dorsal border gently convex; anterior cardinal angle $145^{\circ}$; anterior border with a great radius of curvature, maximum convexity located low $(60 \%$ of height); ventral border gently convex; posterior border with maximum convexity located at mid-height; posterior cardinal angle $125^{\circ}$; small spine close to posterior cardinal angle, shoulder in prolongation of it, which joins dorsal border; carapace flattened all around free margins; surface smooth.

Dimensions. $L=0.76-0.80 \mathrm{~mm} ; H=0.54-0.58 \mathrm{~mm}$.

Discussion. This species has unique characteristics.

Figs 1-7. Hollinella (Praehollinella) hydraensis Crasquin-Soleau n.sp. (sample 50146) fig. 1: right lateral view, holotype, MGL74301, $\times 50$. fig. 2: right lateral view, MGL74302, $\times 50$. Fig. 3: left lateral view, paratype, MGL74303, x60. Fig. 4: right lateral view, MGL74304, $\times 70$. Fig. 5: left lateral view, paratype, MGL74305, ×70. Fig.6: left lateral view, MGL74306, $\times 70$. Fig.7: right lateral view, MGL74307, $\times 70$. fig. 8. Knightina cf. unnoda (Wang, 1978), right lateral view, MGL74308, $\times 70$, sample 50230. fig. 9. Knightina? sp., right lateral view, MGL74309, $\times 35$, sample 90-46. fig. 10. Parvikirkbya cf. fueloepi Kozur, 1985, right lateral view, MGL74310, $\times 60$, sample 90-18. fig. 11. Kirkbyella sp., left lateral view, MGL74311, $\times 50$, sample 90-59. fig. 12. Amphissites sp., right lateral view of broken carapace, MGL74312, $\times 70$, sample 50179. figs 13-14. Knoxiella cf. oblonga Wang, 1978. fig. 13. left lateral view, MGL74313, ×70, sample 50146. fig. 14. left lateral view, MGL74314, $\times 50$, sample $90-44$. 


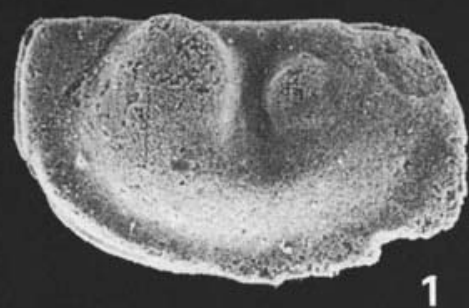

1
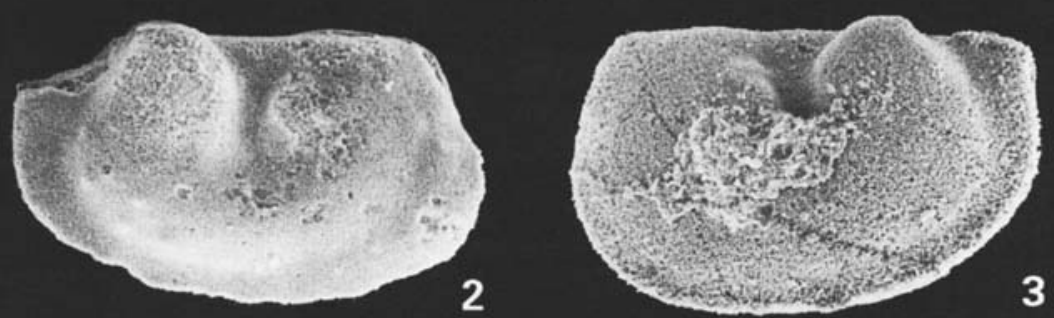

3
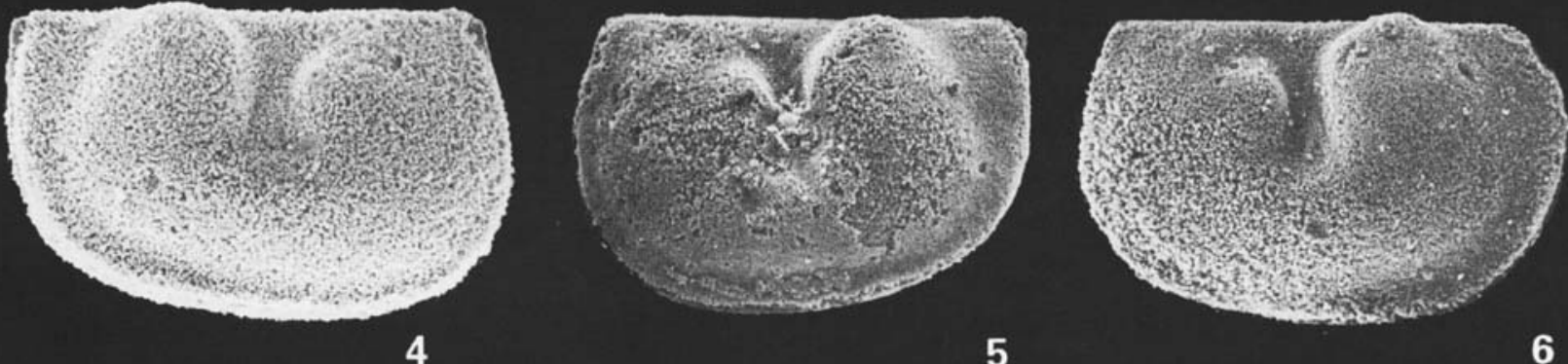

5
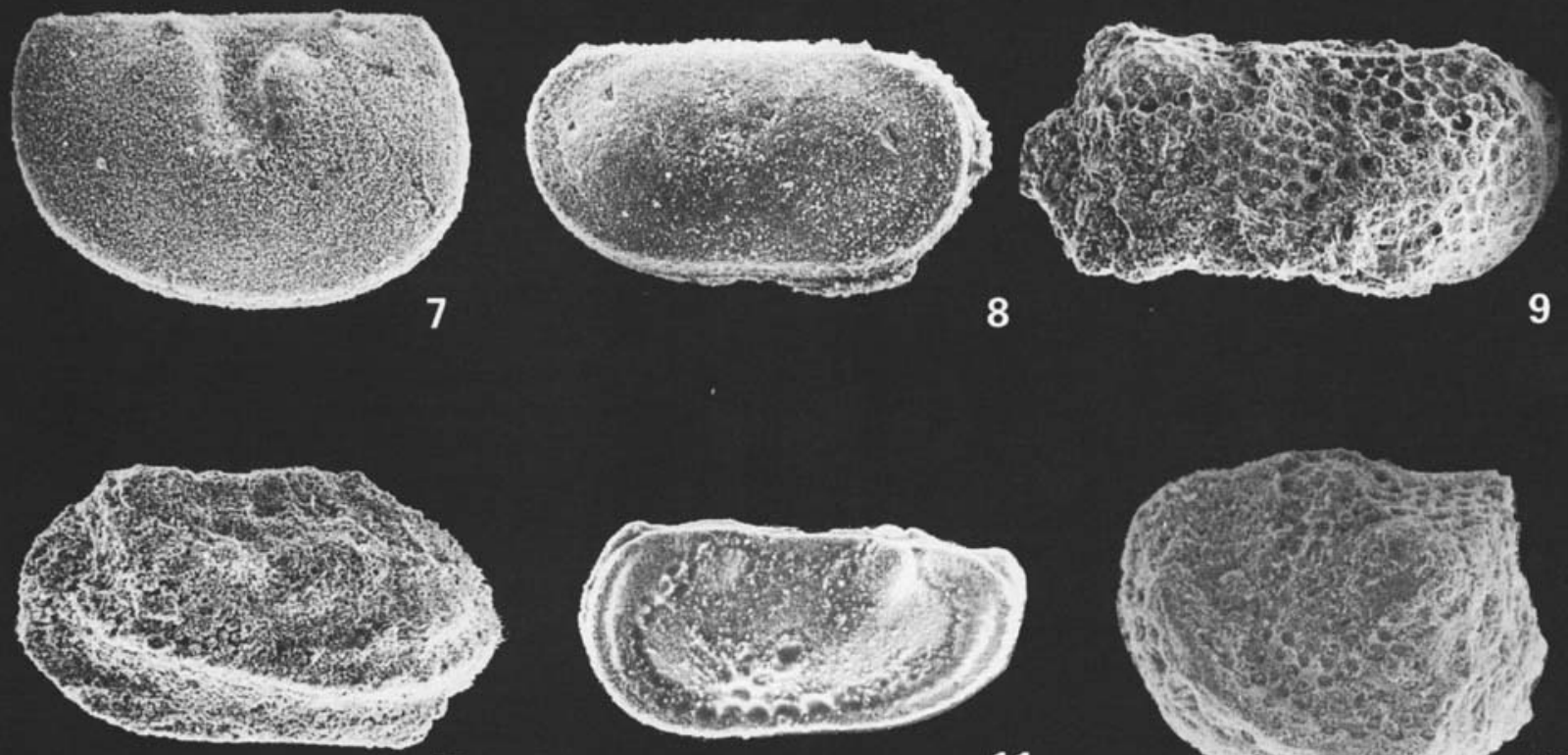

10

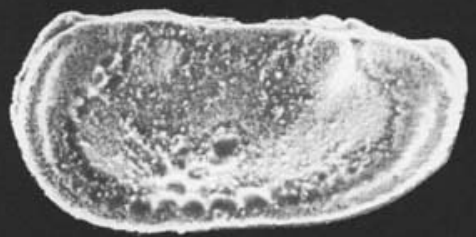

11
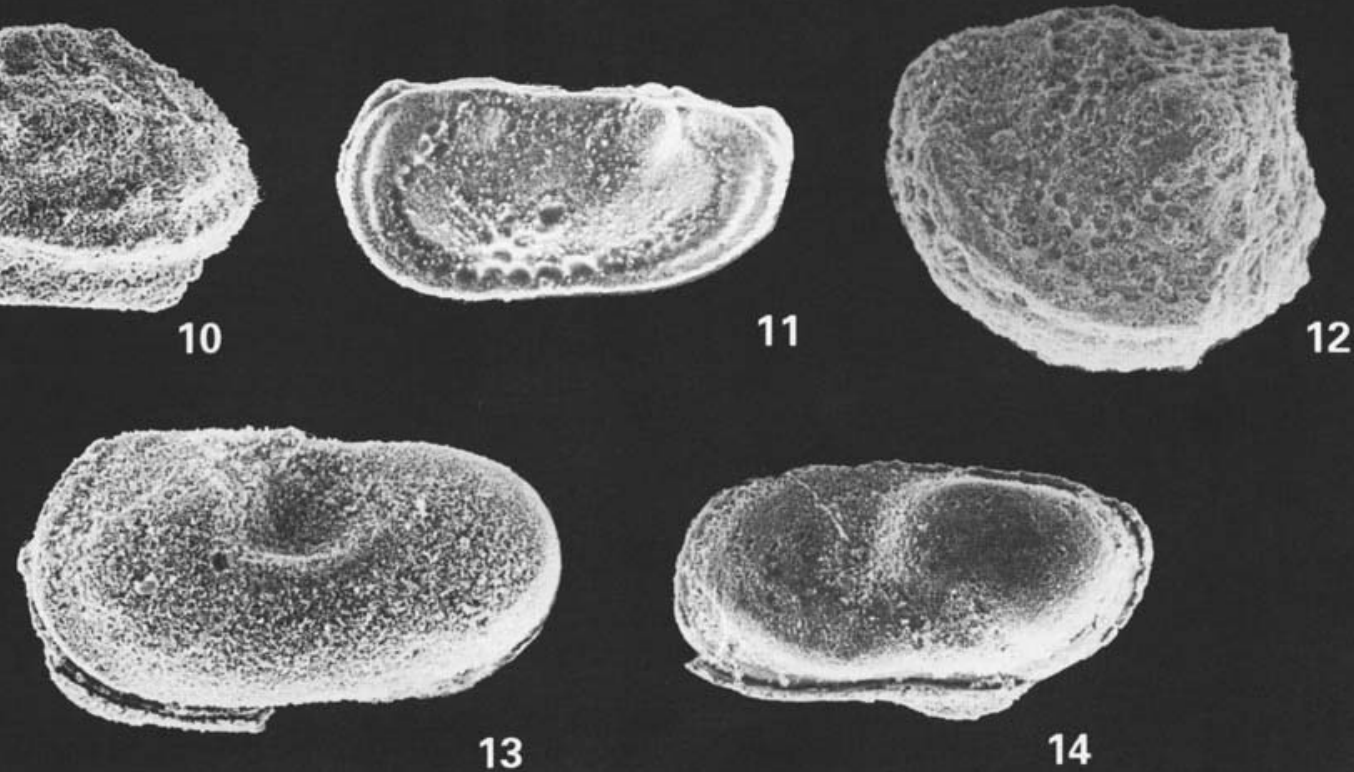

13

14 


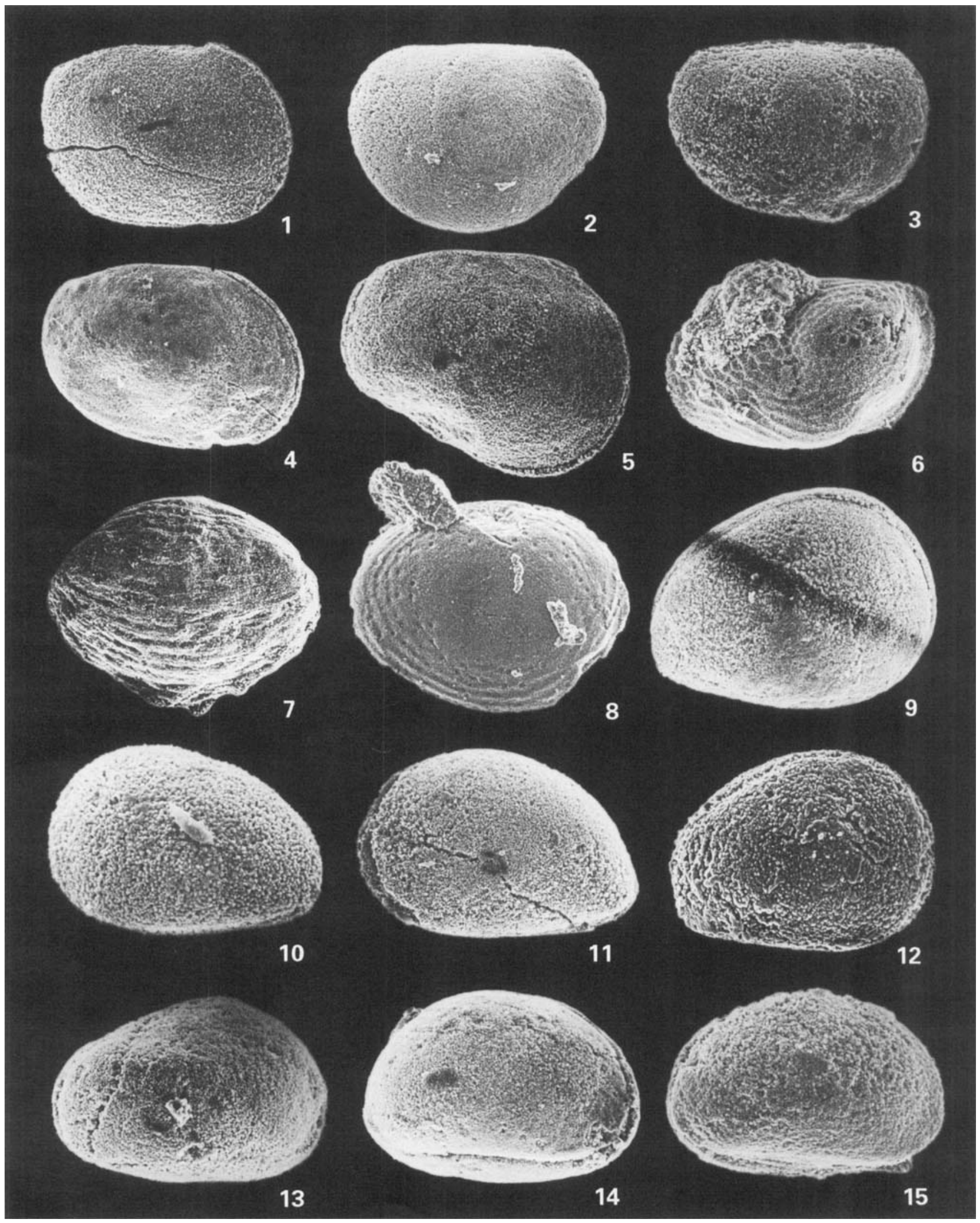


New Permian ostracods from Greece

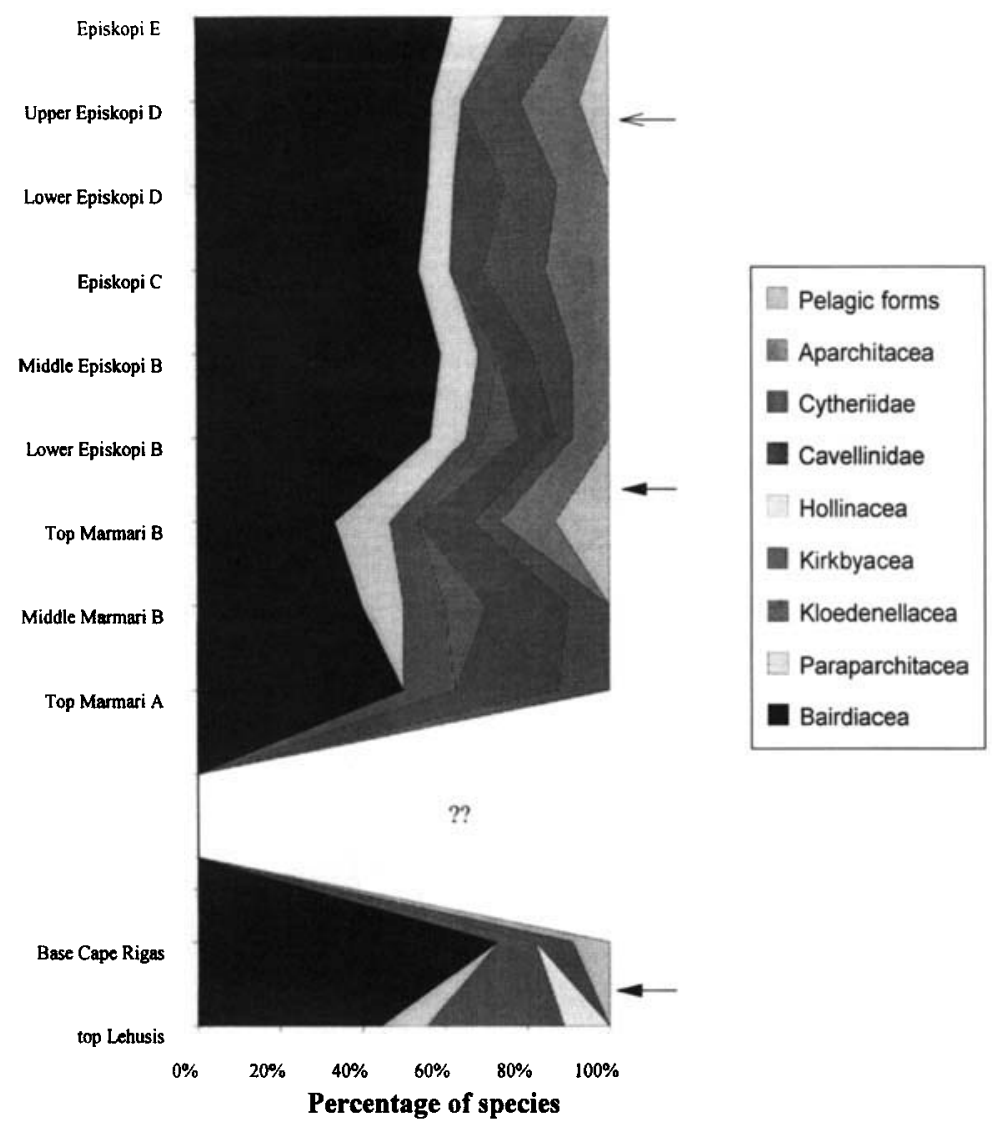

Fig. 5. Distribution of families and/or superfamilies for the Permian of Hydra (in percentage of species). Arrows point out the means variation events in the evolution of the ostracod communities.

Genus Chamishaella Sohn, 1971

Chamishaella marmariensis Crasquin-Soleau n.sp. (P1. 4, figs 12, 14-15)

Derivation of name. From the Marmari Formation, where the type level is located.

Diagnosis. Carapace small, shoulder of dorsal border located at mid-length, carapace flattened laterally along the free margins. Types. Holotype, carapace MGL74326 (Pl. 4, fig. 12); paratype, carapace MGL74328 (Pl. 4, fig. 15).

Type level. Sample 90-40, Hydra Island (Greece), Episkopi section, Marmari Formation, Late Murgabian.

Material. Seven complete carapaces, some isolated valves.

Geographic and stratigraphic occurrences. Hydra Island, Epis- kopi section (samples 90-40, 90-59, 48585), Marmari and Episkopi Formations, Late Murgabian-Dorashamian.

Description. Species small for the genus; dorsal border straight at left valve, convex at right valve; anterior cardinal angle $=145-150^{\circ}$, posterior cardinal angle $=140^{\circ}$; anterior border with large radius of curvature, maximum convexity located slightly below mid-height; ventral border regularly arched, maximum height located at mid-length or slightly posteriorly; posterior border with medium radius of curvature, maximum convexity located at $47 \%$ of heigth; left valve overlaps right one all along free margins; carapace flattened laterally all along free margins; surface smooth.

Dimensions. $L=0.46-0.53 \mathrm{~mm} ; H=0.31-0.44 \mathrm{~mm}$.

Discussion. This small species may be compared to Dentopar-

\section{Explanation of Plate 6}

fig. 1. Paraparchites sabakajensis Kotschetkova, 1972, right lateral view, MGL74330, $\times 60$, sample $90-43$. fig. 2. Shemonaella sp., left lateral view, MGL74331, $\times 80$, sample 50233. fig. 3. Paraparchites sp., right lateral view, MGL74332, $\times 35$, sample 90-57. figs 4-5. Shishaella hellenensis CrasquinSoleau n.sp. (sample 90-46). fig. 4: right lateral view, holotype, MGL74333, $\times 60$. Fig.5. right lateral view, paratype, MGL74334, $\times 70$. fig. 6. Parabythocythere sp.1, left lateral view, MGL74335, $\times 100$, sample 50171. fig. 7. Richterina?. sp., right lateral view, MGL74336, $\times 70$, sample 48539 . fig. 8. Polycope? sp.1, right lateral view, MGL74337, $\times 60$, sample 90-43. figs 9, 12. Basslerella tota Chen \& Bao, 1986 (sample 90-58). Fig.9. right lateral view, MGL74338, x120. fig. 12: right lateral view, MGL74339, $\times 120$. figs 10-11. Basslerella? sp.1. fig. 10: right lateral view, MGL74340, $\times 150$, sample 48531. fig. 11: right lateral view, MGL74341, ×110, sample 50148. fig. 13. Cavellina visnyoensis? Kozur, 1985, left lateral view, MGL74342, $\times 120$, sample 48585. figs 14-15. Praepilatina sp. fig. 14: right lateral view, MGL74343, $\times 100$, sample 90-59. fig. 15: right lateral view, MGL74344, $\times 110$, sample $90-18$. 


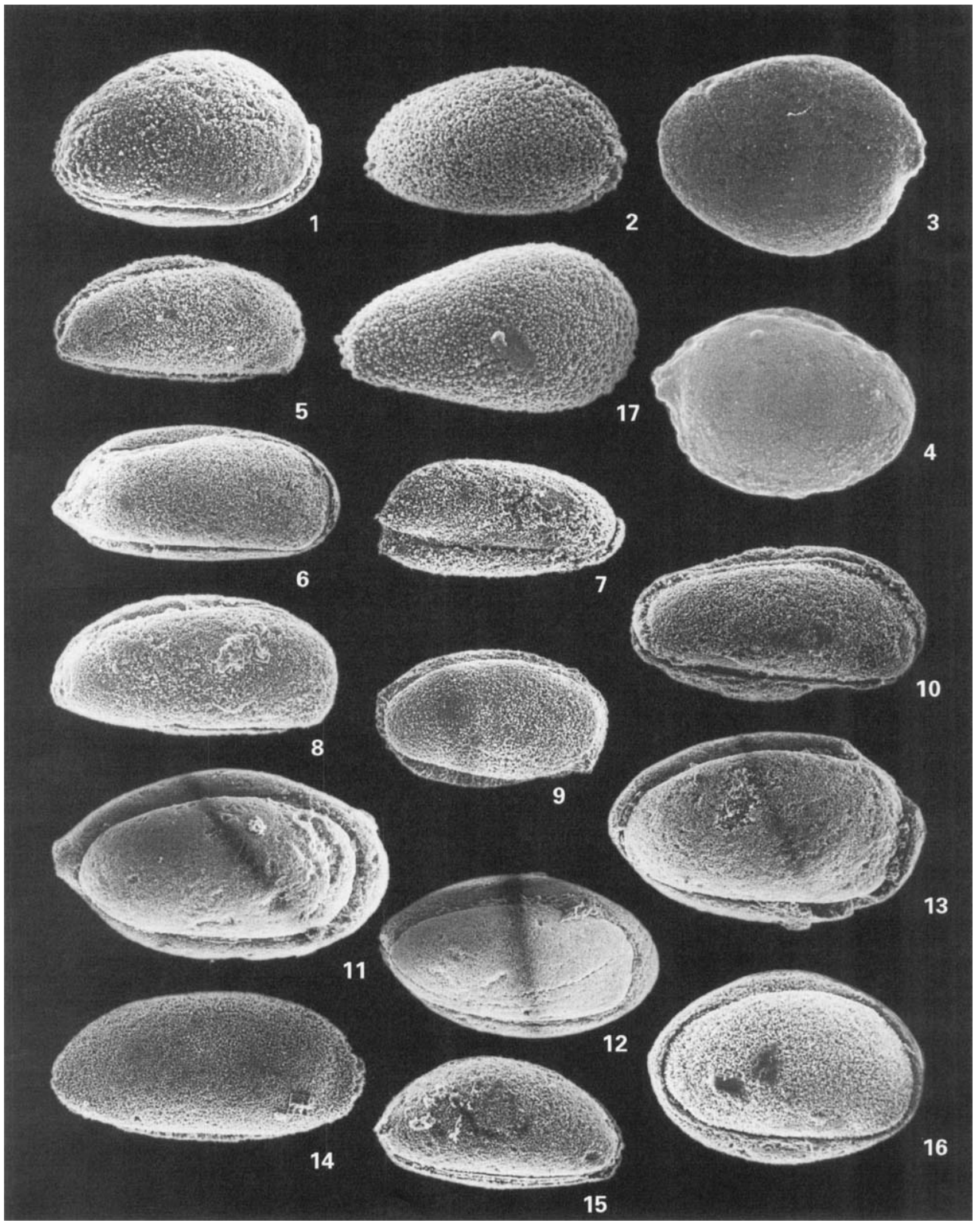


aparchites zalanyii Kozur, 1985 of the Lower Abadehian of Hungary; the general outline is very similar but it lacks the denticulation characteristic of this genus. Chamishaella brosgei Sohn, 1971 from Upper Mississippian of Alaska (USA) is also close to this new species, but here the shoulder is in a more central position and the anterior border has a smaller radius of curvature.

\author{
Order Myodocopida Müller, 1894 \\ Family Cypridinidae Baird, 1850 \\ Genus Cypridina Milne-Edwards, 1840 \\ Cypridina gussevaae Crasquin-Soleau n.sp.
}

(Pl. 7, figs 3-4)

Derivation of name. In honour of Dr Ekaterina Gusseva, St. Petersburg (Russia).

Diagnosis. Carapace round with small rostral notch.

Types. Holotype, carapace MGL74347 (P1. 4, fig. 3); paratype, carapace MGL74348 (Pl. 4, fig. 4).

Type Ievel. Sample 90-43, Hydra Island (Greece), Episkopi section, Marmari Formation, Late Murgabian.

Material. Five carapaces

Geographic and stratigraphic occurrences. Hydra Island, Cape Bisti section (sample 90-33), Episkopi section (sample 90-43), Marmari Formation-Episkopi Formation, Late MurgabianDzulfian.

Description. Dorsal border regularly arched; anterior border with typical rostral notch; ventral and posterior borders regularly arched; carapace smooth, slightly laterally compressed in anterior part; right valve slightly overlaps the left one.

Dimensions. $L=0.41-0.60 \mathrm{~mm} ; H=0.31-0.43 \mathrm{~mm}$.

Discussion. This species is comparable to Cypridina ovata Gusseva, 1986 (in Gusseva et al., 1986) from the Lower Permian of Russian Platform, but in our species the posterior border is round and the rostral notch is smaller.

\section{PALAEOECOLOGY}

The general composition of this marine ostracod assemblages for the entire composite section is typical of a shallow platform under tropical conditions, so characteristic of the Palaeotethys realm at this time. The Bairdiacea dominate (56\% of the species) other benthic superfamilies and families, with specimens larger than $1 \mathrm{~mm}$. A few pelagic species without palaeoecological significance are associated with the Paraparchitacea, Kloedenellacea, Hollinacea, etc. This is characteristic of Late Palaeozoic open platforms, with calm conditions under a warm climate. Following the discussion of Lethiers et al. (1989) on the Late Permian environments of the Marls of Merbah el Oussif (Tunisia), we can add that the encountered ostracod genera are known to be benthic, shallow-marine forms, living near the water-sediment interface or on vegetation matter. The ecological requirements of some species have already been detailed for the Lower Permian of Texas (Melnyk \& Maddocks, 1988) and Kansas (Peterson \& Kaesler, 1980; Costenzo \& Kaesler, 1987). For example, the Bairdiacypris group belongs to a nearshore group of species. Large Hollinella, with developed adventral structure, can characterize an environment such as an interdistributary bay prodelta and interdeltaic embayment lagoons (lowermost level of the section). The Bairdia group characterizes carbonate, open-marine environments. Carapaces are often broken and most of the well-represented species show only adults and last-larval stages (except for Hollinella hydraensis Crasquin-Soleau n.sp. which yields larval stages). This is a consequence of a high-energy biocenosis or a thanatocoenosis (Whatley, 1983, 1988; Brouwers, 1988). However, transportation was limited since most individuals are represented by closed carapaces, indicating a soft substratum and a relatively high sedimentation rate (Oertli, 1971). However, some small variations are identifiable within these general characteristics along the section.

The general ecological changes are summarized in Fig. 5. At the top of the Lehusis Formation, the percentage of Bairdiacea is low $(45 \%)$ and the Kloedenellacea, characteristic of very shallow environments where salinity conditions can be very variable, abound together with the Hollinacea (the only level of the section). At the base of the Cape Rigas formation, the percentage of Bairdiacea increases very significant $(70 \%$ of species), with less Kloedenellacea, and without Hollinacea: this environment is deeper, with more stable living conditions.

After a gap (no ostracods found in the studied samples) along Cape Rigas, Riga, Cape Bisti and lower Marmari formations, we have in the Marmari a relatively homogeneous composition with low percentages of Bairdiacea, Paraparchitacea, Kloedenellacea: this represents a typical shallow platform environment. Nevertheless, a small event occurs at the boundary of the Marmari and Episkopi formations where the percentage of Bairdiacea increases together with the progressive disappearance of Kloedenellacea. This indicates a rapid deepening of the sea and the optimum marine environment for the construction of the last Permian carbonate platform. This event is correlated with the C event of Baud et al. (1991).

\section{PALAEOBIOGEOGRAPHIC RELATIONSHIPS}

The Hydra ostracod fauna contains a great number of new

\section{Explanation of Plate 7}

fig. 1. Praepilatina? sp.2, right lateral view, MGL74345, $\times 100$, sample 48631 . fig. 2. Basslerella sp. 2 , right lateral view, MGL74346, $\times 120$, sample 90 58. figs 3-4. Cypridina gussevaae Crasquin-Soleau n.sp. fig. 3: right lateral view, holotype, MGL74347, $\times 120$, sample 90-43. fig. 4: left lateral view, paratype, MGL74348, $\times 80$, sample 90-33. figs 5-9. Microcheilinella postspinosa Chen, 1958. fig. 5, 7: right lateral view, MGL74349, $\times 75, \times 70$ sample 50224. fig. 6: right lateral view, MGL74350, $\times 80$, sample 90-59. fig. 8: right lateral view, MGL74351, $\times 100$, sample 48361. fig. 9: right lateral view, MGL74352, $\times 60$, sample 50201. fig. 10. Microcheilinella cf. hungarica Kozur, 1985, right lateral view, MGL74353, $\times 100$, sample. 90-46. figs 11-13. Microchelinella peroi peroi Kozur, 1985 (sample 90-59). fig. 11: right lateral view, MGL74354, $\times 80$; fig. 12: right lateral view, MGL74355, $\times 70$. fig. 13: right lateral view, MGL74356, x100. fig. 14. Fabalicypris obsoleta (Schneider, 1966), left lateral view, MGL74357, $\times 100$, sample 90-58. fig. 15. Acratia sp.1, right lateral view, MGL74358, $\times 60$, sample 90-58. fig. 16. Microcheilinella sp., right lateral view, MGL74359, $\times 100$, sample 50148. fig. 17: Basslerella ef. acuta Kotschetkova, 1972, right lateral view, MGL74417, ×175, sample 48531 . 


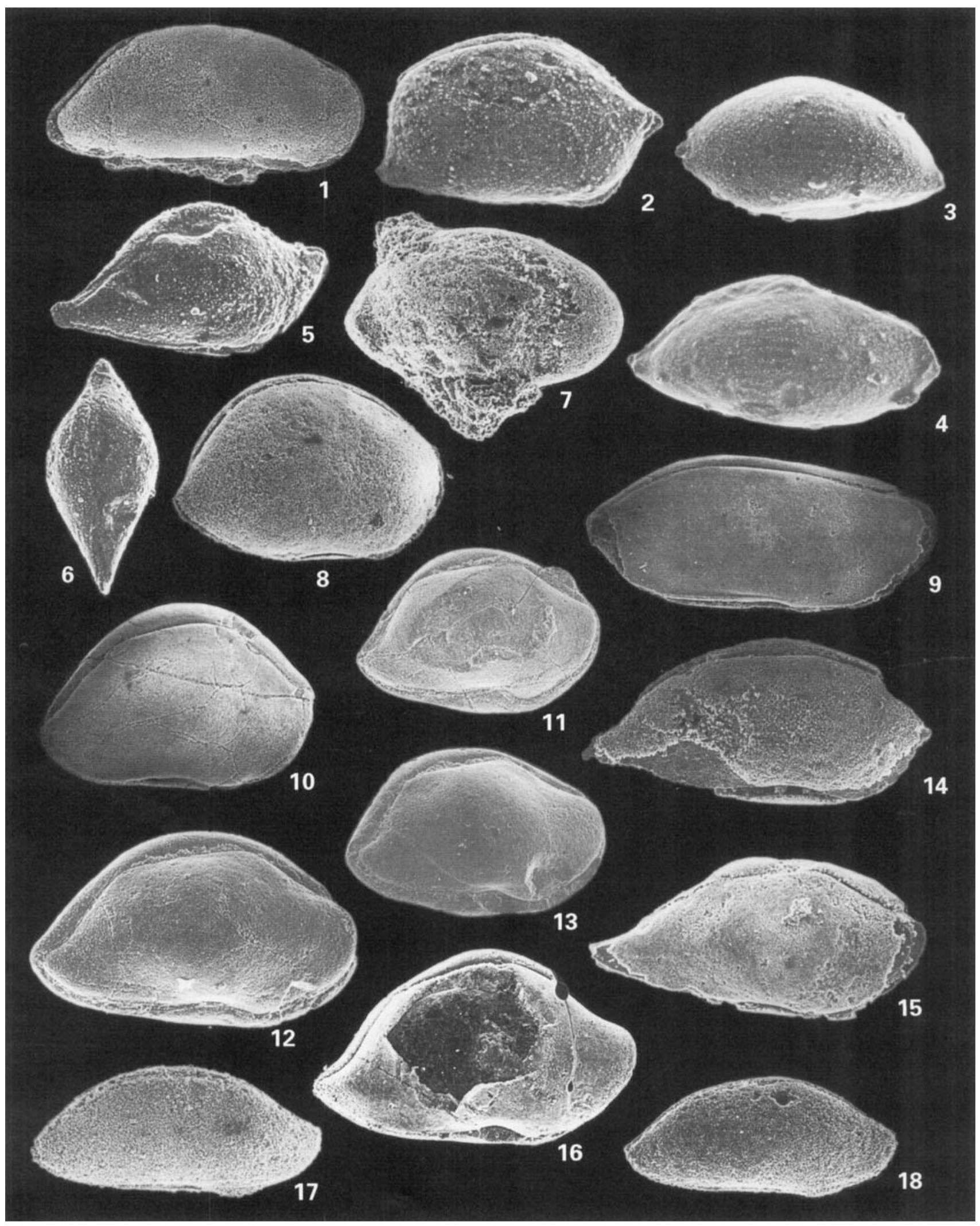


species, which is not surprising as there have been few published studies on the Permian ostracods from this area. In contrast, Permian ostracods are relatively well known in the USA and Russia (see exhaustive bibliography in Lethiers \& CrasquinSoleau, 1995). Available data on the Permian Tethys domain s.l., besides Greece (Kornicker \& Sohn, 1976; Sohn, 1978) come from Hungary (Zalanyi, 1974; Kozur, 1985a, b,), Sicily (Kozur, 1991a, b), Tunisia (Lethiers et al., 1989; Said-Benzarti \& Crasquin-Soleau, 1997), Israel (Gerry et al., 1987), and South China (Chen, 1958; Wang, 1978; Chen \& Bao, 1986; Chen \& Shi, 1982). Some punctual studies were carried out in Japan by Ishizaki (1964).

Figure 6 establishes the relationships between the Hydra Island ostracod fauna and the other ones from known Permian localities. The last line presents the number of common species and the number of species compared to forms belonging to other Permian localities. For clarity, we can use the 'provincialism index' (Johnson, 1971) $P I\left(P I=C / 2 E_{\mathrm{i}}\right)$, where $C$ is the number of common species between two areas and $E_{\mathrm{i}}$ the number of endemic species in the area where they are at their lowest number. We observe that the relationships of the Hydra taxa are close to those of Hungary $(P I=0.14$ and 0.17 with the affine species); this was expected as Hungary is the nearest site to Hydra palaeogeographically. After that, in decreasing order, we note the relations with South China $(P I=0.08-0.14)$, the Russian Platform $(P I=0.05-0.10)$, Tunisia $(P I=0.02)$, Israel $(0.02)$ and the USA $(P I=0.01-0.05)$. The most interesting aspect is the significant palaeobiogeographic relationships between Hydra Island and South China during Permian time. This could be explained by the importance of surface palaeocurrents from East to West in the Palaeotethys realm (Lethiers \& CrasquinSoleau, 1995) that would have dispersed the taxa.

\section{CONCLUSION}

The present study of Permian ostracods from Greece recognizes 66 species and provides 12 new ones. The palaeoecological setting is typically of a shallow marine, carbonate platform environment under a tropical climate, but varying conditions were also recognized.

The palaeobiogeographical relationships point out connections between Hydra and Hungary, South China and the Russian Platform, and these emphasize the importance of the dispersal of ostracod fauna in the Tethyan realm during Permian times.

\section{ACKNOWLEDGEMENTS}

The authors are very gratefull to Prof. Peter J. Jones (Canberra,
Australia) and to Dr Heinz Kozur (Budapest, Hungary) for their accurate examination and review of the manuscript. Even though we are not always in agreement regarding several systematic determinations, the first author would like to express to them her friendship and her respect. They thank Dr Patrick De Deckker (Australian National University) for his very kind help in the last version of the manuscript.

\section{Manuscript received January 1997 Manuscript accepted September 1998}

\section{References}

Angiolini, L., Dragonetti, L., Muttoni, G. \& Nicora, A. 1992. Triassic stratigraphy in the island of Hydra (Greece). Rivista italiana di paleontologia e stratigrafia, 98: 137-180.

Baud, A., Jenny, C., Papanikolaou, D., Sideris, C. \& Stampfli, G. 1991. New observations on Permian stratigraphy in Greece and geodynamic interpretation. Bulletin of the Geological Society of Greece, 25: 187206.

Baud, A., Marcoux, J., Giraud, R., Ricou, L. E. \& Gaetani, M. 1993. Late Murghabian Palaeoenvironments (266 to $264 \mathrm{Ma}$ ). In Dercourt, J., Ricou, L. E. \& Vrielynck, B. (Eds), Tethys Atlas Palaeoenvironmental Maps. BEICIP-FRANLAB, 9-20.

Belousova, Z. D. 1965. Evolution and succession of organisms at the Paleozoic-Mesozoic boundary. Trudy Paleontologiceskogo Instituta Akademia Nauk. SSSR, 108: 245-265 (in Russian).

Bradfield, H. H. 1935. Pennsylvanian Ostracoda of Ardmore Basin, Oklahoma. Bulletins of American Paleontology, 22: 1-145.

Brouwers, E. M. 1988. Sediment transport detected from the analysis of ostracod population structure: an example from the Alaskan continental shelf. In De Deckker, P., Colin, J.-P. \& Peypouquet, J.P. (Eds): Ostracoda in Earth Sciences, 231-244, Elsevier, Amsterdam.

Chen, D.-q. \& Bao, H. 1986. Lower Permian ostracodes from the Chisia formation of Jurong and Longtan, Jiangsu Province. Acta Micropaleontologica Sinica, 3: 107-132 (in Chinese).

Chen, D.-q. \& Shi, C.-g. 1982. Latest Permian ostracoda from Nantong, Jiangsu and from Miannyang, Hubei. Bulletin of Nanjing Institut of Geology and Palaeontology, Academia Sinica, 4: 105-152 (in Chinese).

Chen, T. C. 1958. Permian ostracods from the Chihsia limestone of Lungtan, Nanking. Acta Palaeontologica Sinica, 6: 215-257 (in Chinese).

Costenzo, G. V. \& Kaesler, R. L. 1987. Changes in Permian marine ostracod fauna during regression, Florena shale, northeastern Kansas. Journal of Paleontology, 61: 1204-1215.

Coryell, H. N. \& Sample, C. H. 1952. Pennsylvanian ostracoda. A study of the ostracoda fauna of the East Mountain shale, Mineral Wells Foramtion, Mineral Wells, Texas. American Midland Naturalist, 13: 245-281.

Gerry, E., Honingstein, A., Derin, B. \& Flexer, A. 1987. Late Permian Ostracodes of Israel. Taxonomy, distribution and paleogeographical implications. Senckbergiana lethaea, 68: 197-223

Glebovskaja, E. M. 1939. Upper Palaeozoic ostracods from Northern

\section{Explanation of Plate 8}

fig. 1. Paramacrocypris schallreuteri Kozur, 1985, right lateral view, MGL74373, $\times 50$, sample 50148. fig. 2. gen. sp. Indet. (Bairdia? sp.), right lateral view?, MGL74374, $\times 80$, sample 48585. figs 3-4. Acratia? cf. striatula Shi, 1987 (sample 90-54). fig. 3: right lateral view, MGL74375, $\times 90$. fig: 4. right lateral view, MGL74375, ×80. figs 5-6. Urobairdia sp. sensu Gerry et al., 1987 (sample 50201, $\times 70$ ). fig. 5: right lateral view, MGL74376. Fig. 6. Dorsal view, MGL74377. fig. 7. Bairdia cf. forakerensis Kellett, 1934 sensu Glebovskaya, 1939, right lateral view, MGL74378, $\times 75$, sample 90-46. fig. 8. Bairdia cf. folgeri Kellett, 1934, right lateral view, MGL74379, $\times 80$, sample 90-59. fig. 9. Bairdia magna Kotschetkova, 1972, right lateral view, MGL74380, $\times 35$, sample 90-46. figs 10-13, 16. Bairdia deducta deducta (Zalanyi, 1974). fig. 10: right lateral view, MGL74381, $\times 35$, sample 90-59. Fig.11. right lateral view, MGL74382, $\times 35$, sample 90-43. Fig.12. right lateral view, MGL74383, x50, sample 90-43. fig. 16: right lateral view, MGL74384, $\times 40$, sample 90-59. figs 14-15. Bairdia sp. E. fig. 14: right lateral view, MGL74385, $\times 50$, sample 50203. fig. 15: right lateral view, MGL74386, $\times 70$, sample 90-46. figs 17-18. Bairdia cf. subcontracta Chen, 1987. fig.17: right lateral view, MGL74387, $\times 60$, sample 90-58. fig. 18: right lateral view, MGL74388, ×70, sample 90-51. 
Fig. 6. Table identifying the palaeobiorelationships between Hydra Island ostracod taxa and those from other known localities for Permian time. $1-$ from Kozur (1985a,b), Zalanyi (1974); 2-from Chen \& Bao (1986), Shi (1987), Shi \& Chen (1987), Wang (1978), Chen (1958); 3 -from Lethiers et al. (1989), Said-Benzarti \& Crasquin-Soleau (1997); 4 - from Ulrich \& Bassler (1906), Kellett (1934), Harris \& Lalicker (1932), Coryell \& Sample (1952); 5 -from Gerry et al. (1987); 6-from Glebovskaya (1939), Kotschetkova (1972), Schneider (1966).

\begin{tabular}{|c|c|c|c|c|c|c|c|}
\hline & endemic & $\begin{array}{c}\begin{array}{c}\text { Hungaria } \\
1\end{array} \\
\end{array}$ & $\begin{array}{c}\text { South China } \\
2 \\
\end{array}$ & $\begin{array}{c}\text { Tunisia } \\
3\end{array}$ & $\begin{array}{c}\text { USA } \\
4\end{array}$ & $\begin{array}{l}\text { Israel } \\
5\end{array}$ & $\begin{array}{c}\text { Russian PF } \\
6\end{array}$ \\
\hline "Acratia pulchra POSNER" in CHEN \& BAO, $1986^{*}$ & & & 5 & & & & \\
\hline Acratia cf. schreteri KOZUR, 1985 & & 7 & & & & & \\
\hline Acratia sp. I & $\mathbf{\square}$ & & & & & & \\
\hline Acrasia sp. 2 & 7 & & & & & & \\
\hline Acratia? cf. striatula SHI, 1987 & & & $\boldsymbol{8}$ & & & & \\
\hline Acratina gussevae KOZUR, 1985 & & $\mathbf{5}$ & & & & & \\
\hline Amphissites sp. & $\mathbf{7}$ & & & & & & \\
\hline Bairdia of folgeri KELLETT, 1934 & & & & & $\overline{8}$ & & \\
\hline Bairdia cf. forakesensis KELETT. 1934 sensu GLEBOVS., 1939 & & & & & & & $\delta$ \\
\hline Bairdia cf. subcontracta CHEN, 1987 & & & $\boldsymbol{\sigma}$ & & & & \\
\hline Bairdia deducta deducta (ZALANYI, 1974) & & $\mathbf{5}$ & $\overline{7}$ & & & & \\
\hline Bairdia episkopiensis n.sp. & $\boldsymbol{7}$ & & & & & & \\
\hline Bairdia galei CRON. \& THUR., 1939 in CHEN \& BAO, $1986^{* *}$ & & & 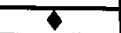 & & & & \\
\hline Bairdia ishizakii n.sp. & $\mathbf{7}$ & & & & & & \\
\hline Bairdia magna KOTSCHETKOVA, 1972 & & & & & & & $\overline{5}$ \\
\hline Bairdia rigasensis $\mathrm{n}$.sp. & (一) & & & & & & \\
\hline Bardia sp. A & 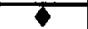 & & & & & & \\
\hline Bardia sp. B & $\square$ & & & & & & \\
\hline Bairdia sp.C & 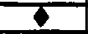 & & & & & & \\
\hline Bairdia thikiaensis n.sp. & $\overline{7}$ & & & & & & \\
\hline Bairdia? sp.D & 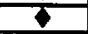 & & & & & & \\
\hline Bairdiacypris bistiensis n.sp & 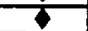 & & & & & & \\
\hline Bairdiacypris deloi BRADFIELD, 1935 & & & & 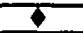 & ד & & $\mathbf{\square}$ \\
\hline Bairdiacypris sp. 1 & 7 & & & & & & \\
\hline Bardiacypris ventralls CHEN. 1982*** & & & $\mathbf{7}$ & & & & \\
\hline Basslerella cf, acula KOTSCHETKOVA. 1972 & & & & & & & $\phi$ \\
\hline Basslerella sp.1 & 7 & & & & & & \\
\hline Basslerella sp.2 & 6 & & & & & & \\
\hline Bassierella tota CHEN \& BAO, 1986. & & & $\overline{7}$ & & & & \\
\hline Cavellina visnyoensis? KOZUR, 1985 & & $\bar{\phi}$ & & & & & \\
\hline Chamishaella marmariensis n.sp & $\mathbf{T}$ & & & & & & \\
\hline Cyathus barmariensis n.sp. & 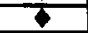 & & & & & & \\
\hline Cyathus klimakiensis n.sp. & 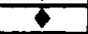 & & & & & & \\
\hline Cypridella aff. stepanovi GLEBOVSKAYA. 1939 & & & & & & & 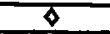 \\
\hline Cypridina gussevaae n.sp. & $\mathbf{C}$ & & & & & & \\
\hline Fabalicypris obsoleta (SCHNEIDFR, 1966) & & & & & & & $\$$ \\
\hline Gen sp. indet. 1 & $\rightarrow$ & & & & & & \\
\hline Gen. sp. indel.2 & 7 & & & & & & \\
\hline Hollinella $(P$.$) hydraensis \mathrm{n} . \mathrm{sp}$ & 7 & & & & & & \\
\hline Indivisia symmetrica KOZUR. 1985 & & 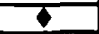 & & & & & \\
\hline Kirkbyella sp. & 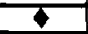 & & & & & & \\
\hline Knightina cf. unnoda (WANG. 1978) & & & 8 & & & & \\
\hline Knightina? sp. & 7 & & & & & & \\
\hline Knuxiella cf oblonga WANG. 1978 & & & 8 & & & & \\
\hline Microcheilinella of hangarica KOZUR, 1985 & & 8 & & & & & \\
\hline Microcheilinella peroi peroi KOZUR, 1985 & & 9 & & & & & \\
\hline Microcheilinella posispinosa CHEN, 1958 & & & $\$$ & & & & \\
\hline Microcheslinella sp. sensu BENZ.SAID \& CRAS., 1997 & & & & $\mathbf{t}$ & & & \\
\hline Parabythocythere sp.1 & 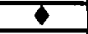 & & & & & & \\
\hline Paramacrocypris schallreuteri KOZUR, 1985 & & 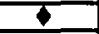 & & & & & \\
\hline Paraparchiles sabakajensis KOTSCHETKOVA. 1972 & & & & & & & 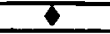 \\
\hline Paraparchites sp. & 7 & & & & & & \\
\hline Parvikirkbya cf. fueloepi KOZUR. 1985 & & 6 & & & & & \\
\hline Petasobairdia kozuri n.sp. & 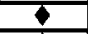 & & & & & & \\
\hline Polycope? sp. & $\overline{\mathbf{T}}$ & & & & & & \\
\hline Praepilatima sp. 1 & 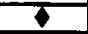 & & & & & & \\
\hline Praepilatina? sp.2 & $\overline{5}$ & & & & & & \\
\hline Praezabythocypris subiriangularis KOZUR, 1985 & & 7 & & & & & \\
\hline Richterina? sp & 6 & & & & & & \\
\hline Shemonaella sp & 7 & & & & & & \\
\hline Shishaella cf hellemensis n.sp. & 7 & & & & & & \\
\hline Shishaella hellenensis n.sp. & 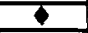 & & & & & & \\
\hline Shivaella cf. brazoensis (CORYELL \& SAMPLE, 1952) & & & & & 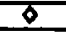 & & \\
\hline Sulcella mesopermiana? KOZUR, 1985 & & $\overline{7}$ & & & & & \\
\hline Sulcella superpermiana KOZUR. 1985 & & 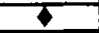 & & & & $\delta$ & \\
\hline Eirobairdia sp. sen.su GERRY et al. 1987 & & & & & & 5 & \\
\hline 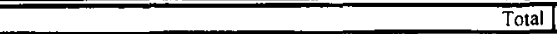 & 34 & $10+2$ & $\overline{6+4}$ & 2 & 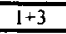 & $1+1$ & $4+3$ \\
\hline $\mathrm{IP}=\mathrm{C} / 2 \mathrm{E}_{\mathrm{i}}$ & & $\begin{array}{l}0.14 / \\
0.17\end{array}$ & $\begin{array}{l}0.08 / 1 \\
0.14\end{array}$ & $\overline{0.02}$ & $\begin{array}{l}0.011 \\
0.05\end{array}$ & $\begin{array}{l}0.011 \\
0.02\end{array}$ & $\begin{array}{l}0.051 \\
0.10\end{array}$ \\
\hline
\end{tabular}

* This is the species figured by Chen \& Bao (1986), but this is not Acratia pulchra Posner

** This is the species figured by Chen \& Bao (1986), but this is not Bairdia galei Croneis \& Thurman, 1939.

*** Only pl. 12, figs 25, 26, 29 in Chen (1982). 
part of Ural. Trydi NIGRI, A, 115: 165-176 (in Russian)

Grant, R. E. 1995. Upper Permian brachiopods of the superfamily Orthotetoidea from Hydra Island, Greece. Journal of Paleontology, 69: 655-670.

Grant, R. E., Nestell, K., Baud, A. \& Jenny, C. 1991. Permian stratigraphy of Hydra Island, Greece. Palaios, 6: 479-497.

Guan, S-Z. 1985. Late Permian Ostracodes from the Western border of Tarim Basin, Xinjiang. Acta Micropalaeontologica sinica, 2: 237-247 (in Chinese).

Gusseva, E. A., Kashevarova, N. P. \& Molostovskaja, I. I. 1986. Ostracodes. In The Atlas of Characteristic Complexes of the Permian Fauna and Flora of the Urals and Russian Platform. NEDRA, Moscow, 331: 15-28 (in Russian).

Harris, R. W. \& Lalicker, C. G. 1932. New Upper Carboniferous Ostracoda from Oklahoma and Kansas. American Midland Naturalist, 13: $396-409$.

Ishizaki, K. 1964. Middle Permian Ostracodes from the Iwaizaki Limestone, Northeast Japan. Science report of the Tohoku University, Sendai, 36: 139-160.

Ivanova N. O., Kotschetkova N. M., Stepanait, N. E. \& Tkatscheva, I. D. 1975. Ostracoda. In Palaeontological atlas of coal sediments of Ural 131-145. (in Russian).

Jenny-Deshusses, C. \& Baud, A., 1989. Colaniella, foraminifère index du Permien tardif téthysien: propositions pour une taxonomie simplifiée, répartition géographique et environnements. Eclogae Geologicae Helvetiae, 82: 869-901.

Johnson, J. G. 1971. A quantitative approach to faunal province analysis. American Journal of Science, 270: 257-280.

Kellett, B. 1934. Ostracodes from the Upper Pennsylvanian and the Lower Permian strata of Kansas: II. the genus Bairdia. Journal of Paleontology, 8: 120-138.

Khivintseva, E. A.1969. New ostracods from the Kazanian deposits of Orenburg province. Paleontological Journal, 3: 85-94.

Kohn, P. A. \& Dewey, C. P. 1990 . Permian ostracodes from the upper Hueco Formation, Robledo Mountains, New Mexico. The Compass, the Earth-Science journal of Sigma Gamma Epsilon, 67: 217-224.

Kornicker, L. F. \& Sohn, I. G. 1976. Phylogeny, ontogeny and morphology of living and fossil Thaumatocypridacea (Myodocopa: Ostracoda). Smithsonian Contributions to Zoology, 219: 1-214.

Kotschetkova, N. M. 1972. Ostracods form the stratotypic section of Asselain, Tciransk level (Bashkiria, Pre-Ural). Stratigraphy and palaeontology of Precambrian and Palaeozoic of South Ural, 102-115 (in Russian).

Kozur, H. 1985a. Biostratigraphic evaluation of the Upper Paleozoic conodonts, ostracods and holothurian sclerites of the Bükk Mts; Part II: Upper Paleozoic ostracods. Acta Geologica Hungaria, 28: 225-256.

Kozur, H. $1985 b$ Neue Ostracoden Arten aus dem Oberen Mittelkarbon (Höheres Moskovian), Mittel und Oberperm des Bükk Gebirges (N. Ungarn). Geologisch-Paläontologische Mitteillungen Innsbruck, 2: 1145.

Kozur, H. 1991a. Permian deep water ostracods from Sicily (Italy). Part 1: Taxonomy. Geologisch-Paläontologische Mitteillungen Innsbruck, 3: $1-24$.

Kozur, H. $1991 b$. Permian deep water ostracods from Sicily (Italy). Part 2: Biofacial evaluation and remarks to the Silurian to Triassic paleopsychrospheric ostracods. Geologisch-Paläontologische Mitteillungen Innsbruck, 3: 25-38.

Lethiers, F. \& Crasquin-Soleau, S. 1988. Comment extraire des microfossiles à tests calcitiques de roches calcaires dures. Revue de Micropaléontologie, 31: 56-61.

Lethiers, F. \& Crasquin-Soleau, S. 1995. Distribution des ostracodes et paléocourantologie au Carbonifère terminal-Permien. Geobios, 18: 257-272.

Lethiers, F., Duro, E., Crasquin-Soleau, S. \& Fourcade, E. 1995. Premières données sur les ostracodes (Crustacés) permiens du Guatemala (Amérique Centrale). Comptes rendus de l'Académie des Sciences, Paris, 320: 1109-1116.

Lethiers, F., Razgallah, S., Colin, J.-P. \& Vachard, D. 1989.
Micropalaeontology of the Permian Marls of Merbah el Oussif (Jebel tebaga, Tunisia) with special emphasis on the Ostracods. Journal of Micropalaeontology, 8: 227-238.

Melnyk, D. H. \& Maddocks, R. F. 1988. Ostracode biostratigraphy of the Permo-Carboniferous of Central and North-Central Texas, Part I: Paleoenvironmental framework. Micropaleontology, 34: 1-20.

Nestell, M. K. \& Grant, R. E. 1987. Permian fusulinid succession on Hydra, Greece. 11th International Congress on Carboniferous Stratigraphy and Geology, Beijing, Abstracts with Papers, Symposium and Miscellaneous, 2: 471-472.

Nestell, M. K. \& Wardlaw, B. R. 1987. Upper Permian conodonts from Hydra, Greece. Journal of Paleontology, 61: 758-772.

Oertli, H. J. 1971. The aspects of ostracode faunas-a possible new tool in petroleum sedimentology. Bulletin Centre de Recherche Pau-SNPA, 5: $137-151$.

Peterson, R. M. \& Kaesler, R. L. 1980. Distribution and diversity of ostracode assemblages from the Hamlin Shale and the Americus Limestone (Permian, Wolfcampian) in Northeastern Kansas. University of Kansas Paleontological Contributions, 100: 1-26.

Renz, C. \& Reichel, M. 1946. Beitraege zur Stratigraphie und Palaeontologie des ostmediterranen Jungpalaeozoikums und dessen Einordnung im griechischen Gebirgssystem. Eclogae Geologicae Helvetiae, 38: 211-313.

Römermann, H. 1968. Geologie von Hydra (Griechenland). Geologica und Palaeontologica, Marburg, 2: 163-171.

Römermann, H. 1969. Geologie von Hydra (Griechenland). Inaugural Dissertation, Phillips Universität, Marburg, $62 \mathrm{pp}$.

Römermann, H., Graf, W., Huckriede, P., Jacobshagen, V., Kahler, F., Walliser, H., Zapfe, H. \& Borbovas, J. 1981. Hydra: In Collection of Geologic Maps 1:50000, Geological Survey of Greece, Institute for Geology and Subsurface Research (I.G.M.E.), Athens.

Said-Benzarti, R. \& Crasquin-Soleau, S. 1998. Les ostracodes du Permien supérieur de Tunisie reconnu en subsurface. In CrasquinSoleau, S., Braccini, E. \& Lethiers, F. (Eds): "What about Ostracoda!". Bulletin des Centres de Recherches Exploration-Production Elf-Aquitaine, 120 (in press).

Schneider, G. F. 1966. Ostracods from the Upper Permian sediments of the Russian Platform and their stratigraphic significance. Naukova Dumka, 93-108 (in Russian).

Shi, C.-g. 1987. Ostracodes from the Taiyuan Formation of Southeastern Shanxi. Late Paleozoic Coal Bearing Strata and Biota from Southeastern Shanxi, China. 291-306, Nanjing University Press.

Shi, C.-g. \& Chen, D.-q. 1987. The Changhsingian ostracodes from Meishan Changxing, Zhejiang. Stratigraphy and Palaeontology of Systemic Boundaries in China; Permian and Triassic Boundary, 5: 2380 (in Chinese).

Sohn, I. G. 1971. New Late Mississippian Ostracode genera and species from Northern Alaska. A review of the Paraparchitacea. United States Geological Survey Professional Paper, 711A: 1-24.

Sohn, I. G. 1972. Late Paleozoic Ostracode species from the continuous United States. United States Geological Survey Professional Paper, 711B: $1-13$.

Sohn, I. G. 1978. Tribolbina Latham, 1932, an early Carboniferous through Permian Palaeocopid ostracode genus. Journal Reasearch United States Geological Survey, 6: 633-676.

Stow, D. A. V. 1975. New fusulinid evidence for the Permian age of the Palaeozoic rocks of Hydra, Greece. Geological Magazine, 112: 71-76.

Ulrich, E. O. \& Bassler, R.S. 1906. New American Paleozoic Ostracoda. Proceedings of the United States National Museum, 30: 149-164.

Vachard, D., Martini, R. \& Zaninetti, L. 1995. Le Murgabien à fusilinoïdes des îles d'Hydra, Crète et Mytilène (Permien supérieur de Grèce). Geobios, 28: 395-406.

Wang, S.-q. 1978. Late Permian and Early Triassic ostracods of Western Guizhou and Northeastern Yunnan. Acta Palaeontologica Sinica, 17: 277-312 (in Chinese).

Whatley, R. C. 1983. The application of ostracoda to paleoenvironmental analysis. In: Maddocks R. F. (Ed.), Applications of Ostracoda. 51-77, University of Houston Department Geosciences. 
Whatley, R. C. 1988. Population structure of ostracods: some general principles for the recognition of palaeoenvironmets. In De Deckker, P., Colin, J.-P. \& Peypouquet, J.-P. (Eds), Ostracoda in Earth Sciences, 244-256, Elsevier, Amsterdam.
Zalanyi, B. 1974. Die oberpermischen Ostracoden des Bükkgebirges. In Sido, M., Zalanyi, B. \& Schreter, Z. (Eds), Neue paläontologische Ergebnisse aus dem Oberpaläozoikum des Bükkgebirges. 96-251, Akademiai Kiado, Budapest. 